\title{
Öğretmen ve Öğrencilerin Tablet Bilgisayar Kullanımında Yaşadıkları Sorunlar ve Çözüm Önerileri
}

\author{
Problems Faced by Teachers and Students in Terms of Using \\ Tablet PCs and Suggested Solutions Related to these Problems
}

\author{
Levent Çetinkaya \\ Ankara Üniversitesi, Türkiye \\ cetinkayalevent@gmail.com
}

\author{
Hafize Keser \\ Ankara Üniversitesi, Türkiye \\ keser@ankara.edu.tr
}

\begin{abstract}
Özet
Gerçekleştirilen çalışmada ortaöğretim kurumlarında görev yapan öğretmen ve bu kurumlarda öğrenim gören öğrencilerin tablet bilgisayar kullanımı sırasında karşılaştıkları sorunların ve bu sorunlara ilişkin çözüm önerilerinin belirlenmesi amaçlanmışır. Tarama modelinde tasarlanan araştırmada veriler, içerik analizi ile çözümlenerek kategorize edilmiştir. Araştırmanın çalışma grubunu, tablet bilgisayarları aktif olarak derslerinde kullanan farklı branş öğretmenleri $(f=47)$ ve öğrencileri $(f=286)$ oluşturmuştur. Bu kapsamda gerçekleştirilen çalışmada yapılan analizler sonucunda öğretmen ve öğrencilerin tablet bilgisayarlara ilişkin sorunları; öğrenme-öğretme sürecinde yaşanan sorunlar, donanıma yönelik sorunlar, yazılıma yönelik sorunlar, ders içeriklerine yönelik sorunlar, ergonomi ve sağlık açısından yaşanan sorunlar olmak üzere beş alt boyutta ele aldıkları ve bu doğrultuda çözüm önerileri sundukları belirlenmiştir. Tablet bilgisayarlara yönelik öğretmen ve öğrencilerin karşılaştıkları sorunların başında kısıtlamaların (yazıım, içerik ve internet) etkin kullanımı sınırlandırması, derslere uygun materyal bulunamaması, kullanıma yönelik yetersiz bilgi ve becerilere yönelik tedbir alınamaması yer almaktadır. Yaşanan sorunlara ilişkin katıımcıların öne çıkan çözüm önerileri ise; yazılım ve internete yönelik kısıtlamaların kaldırılması gerektiği, uygun ders materyalleri geliştirilmesi gerektiği, öğretmen ve öğrencilere yönelik kapsamlı eğitimler verilmesi gerektiği, yaşanan donanımsal ve yazılımsal sorunların kısa zamanda çözülmesi gerektiği şeklindedir.
\end{abstract}

Anahtar Kelimeler: Tablet Bilgisayar; Tablet Bilgisayar Destekli Öğretim; Teknoloji Temelli Ögrretim; Bilişim Teknolojileri; FATIH Projesi.

\footnotetext{
Abstract

The study aims to determine the problems that are encountered by the teachers and students of high education institutions while using tablet PCs and to develop solution suggestions for these problems. In the study which is conducted as a survey model, the data is categorized by content analysis method. Study group for this research is composed of high educated teachers from different branches $(f=47)$ actively using tablet PCs in the lectures and their students $(f=286)$. As result of the analysis carried out in this research which was performed in this direction, it has been seen that teachers and students evaluate the problems related with tablet PCs under the following five sub-dimensions: problems encountered during learning-teaching process, problems related with hardware, problems related with software, problems related with the context, problems in view of ergonomics and health, and they propose solution suggestions in accordance with these problems. The most common problems that are faced, concerning the usage of the tablet PCs, are the software, context and internet restrictions which limit efficiency, unavailability of suitable materials for lectures, and lack of precautions against insufficient knowledge and skills. Leading
} 
solution alternatives suggested by the participants as regards the problems are; needs for lifting restrictions on software and internet, needs for developing appropriate lecture materials, needs for comprehensive training of teachers and students, needs for a fast solution for the existing hardware and software problems.

Keywords: Tablet PCS; Tablet PCS Aided Instruction; Technology Based Instruction; Information Technology; FATIH Project.

\section{Giriş}

Eğitim teknolojilerindeki ilerlemeler ve bu ilerlemelerin öğrenme-öğretme ortamına sağladığı katkılar teknoloji destekli öğrenmeye olan ilgiyi gün geçtikçe attırmaktadır. Bu doğrultuda ülkemizde 2010 yılının Kasım ayından itibaren Milli Eğitim Bakanlığı ve Ulaştırma Bakanlığının işbirliği ile okulöncesi, ilköğretim ve ortaöğretim kademelerinde dersliklere bilişim teknolojisi araçları sağlanarak, bilişim teknolojisi destekli öğretimin gerçekleştirilmesini hedefleyen FATİH (Fırsatları Arttırma ve Teknolojiyi İyileştirme Hareketi) Projesi'nin uygulanmasına yönelik çalışmalar başlamıştır (MEB, 2011). Ülkemizde bilişim teknolojisi destekli öğretimin gerçekleştirilmesini hedefleyen FATİH projesi çerçevesinde tüm ortaokul ve ortaöğretim kademelerinde öğrenim gören öğrenciler ve bu kurumlarda görevli öğretmenlere tablet bilgisayar verilmesi planlanmıştır. Bu doğrultuda ülke çapında belirlenen pilot okulların 6. ve 9. Sınıflarda öğrenim gören öğrenciler ve bu sınıflarda ders veren öğretmenlere tablet bilgisayarlar 2012 yılı itibariyle verilmeye başlanmıştır. Öğrenme-öğretmen ortamlarına sunulan bu yeni teknoloji, kablosuz iletişim ve ağ (Geniş Ağ-WLAN ve Yerel Ağ -LAN) erişimine olanak sağlamasından dolayı diğer cihazlarla etkileşim içinde çalışabilen, tümleşik (tüm donanım ve yazılımları bünyesinde barındıran) bir yapıya sahip ve işlemlerin ekran üzerinde yapılabilmesine olanak sağlayan taşınabilir cihazlardır.

Kablosuz iletişim teknolojilerindeki hızlı gelişmeler, her zaman ve her yerde öğrenmeyi mümkün hale getirerek çevrimiçi öğrenme kapsamında yeni öğrenme yöntemlerinin gelişimine katkıda bulunmaktadır. Kablosuz iletişim teknolojilerinden biri olarak kabul edilen tablet bilgisayarlar, kablosuz ağlar üzerinden diğer cihazlarla (bilgisayar, etkileşimli tahta, telefon, vb.) etkileşim içinde çalışabilmektedir. Böylelikle teknoloji-teknoloji ve insan-teknoloji etkileşimi sağlanarak işbirlikli öğrenmeye de katkı sağlayabilmektedir. Ayrıca, interaktif içerikleri (animasyon, video, ses, vb.) destekleyen yapısı ile tablet bilgisayarlar öğrenenlere zamandan ve mekandan bağımsı bir öğrenme ortamı sağlayabilmektedirler. Tüm bu sahip oldukları özelliklerden dolayı tablet bilgisayarlar eğitim alanına yeni bakış açısı getirerek, yeni kazanımlar sağlamada etkili araçlar olarak görülmekte ve öğrenme-öğretme ortamlarında kullanımını gittikçe artmaktadır (Stickel, 2009; Ellington, Wilson, \& Nugent, 2011; Horton, Kim, Kothaneth, \& Amelink, 2011; Mulholland, 2011).

Dünya genelinde tablet bilgisayarlı eğitim ve bu eğitimin kapsamı incelendiğinde FATİH projesi kadar geniş kapsamlı bir çalışmanın Kore'de yapıldığı görülmektedir. Teknolojik gelişmeleri yakından takip eden ve bu teknolojileri eğitimde kullanma çabaları konusunda öncü ülkelerden biri olan Güney Kore'de 2011 yılı sonu itibariyle eğitimde tablet bilgisayar kullanımına yönelik adımlar atılmaya başlanmıştır. Bu doğrultuda ilk aşamada 2012 yılı sonu itibariyle 489 okulda tablet bilgisayarlı eğitim hedeflenmiştir. Güney Kore'de ki bu çalışmanın 2015 yılına kadar hedeflenen kısmında ise ilköğretim ve lise öğrencilerini kapsayacak nitelikte ve tüm müfredatın dijital ders kitapları (digital textbooks) formatında interaktif dijital içerik olarak sunulması planlanmaktadır (BBC, 2011; Smart Education in Korea, 2011; Grzybowski, 2013). Amerika Birleşik Devletlerinde ise 2012 yılından itibaren dijital ders kitaplarına geçiş çalışmaları doğrultusunda tablet bilgisayarlı eğitim çalışmaları hız kazanmaya başlamıştır (Toppo, 2012). Bu doğrultuda Amerika'nın Florida eyaletinde yeni yasa ile birlikte 20152016 öğretim yıllarında K-12 (ilköğretim ve lise) okullarında sadece dijital ders kitaplarının kullanılacağı belirtilmiştir (Ni, 2013). Dünya genelinde bakıldığında, birkaç ülkede (örn., A.B.D., Portekiz, İngiltere, İspanya, Güney Kore) tablet bilgisayarlı eğitim konusunda pilot çalışmaların yapıldığı, ancak hiçbir ülkede tüm ilköğretim ve lise öğrencilerini kapsayan tablet bilgisayarlı eğitime tam anlamıyla geçilemediği görülmektedir.

Tablet bilgisayarların öğrenme-öğretme ortamlarında kullanımına yönelik alan yazın incelendiğinde; kullanımına ilişkin eğilimlerin belirlenmesi (Moran, Hawkes, \& El Gayar, 2010; El-Gayar, Moran, \& Hawkes, 2011; Bozdoğan, \& Uzoğlu, 2012), farklı öğrenme alanlarında kullanımı (Fister, \& McCarthy, 
2008; Rogers, \& Cox, 2008; Galligan, Loch, McDonald, \& Taylor, 2010; Hieb, \& Ralston, 2010; Tofan, 2010; Loch, Galligan, Hobohm, \& McDonald, 2011; Romney, 2011; Yoon, \& Sneddon, 2011; Gök, 2012; Uzoglu, \& Bozdoğan, 2012), eğitsel önemi ve sınırlıkları (Le Ber, Lombardo, \& Quilter, 2008; ElGayar, Moran, \& Hawkes, 2011; Ferrer, Belvi's, \& Pa`mies, 2011; Dundar, \& Akçayır, 2012), öğrenme-öğretme sürecindeki davranışlara etkisi (Roschelle, Tatar, Chaudhury, Dimitriadis, Patton, \& DiGiano, 2007; Stickel, 2009; Amelink, Scales, \& Tront, 2012), değerlendirme ve geribildirim amaçlı kullanımına (Kowalski, Kowalski, \& Gardner, 2009; Siozos, Palaigeorgiou, Triantafyllakos, \& Despotakis, 2009; Enriquez, 2010; Gök, 2012) ilişkin verilerin farklı çalışmalarda incelendiği görülmektedir. Yapılan çalışmaların çoğunda öğretmen ve öğrencilerin de tablet bilgisayarların doğru kullanım stratejileri ile öğrenme-öğretme ortamına getirebileceği muhtemel katkıları ön plana çıkmaktadır. Bu konuda yapılan çalışmalarda elde edilen sonuçlara göre tablet bilgisayarların öğrenmeöğretme ortamına muhtemel katkıları şöyle özetlenebilir:

- Motivasyona olumlu katkısı (Price, \& Simon, 2009; Mills, 2012)

- Her yerde- her zaman öğrenmeyi desteklemesi (Nie, Armellini, Witthaus, \& Barklamb, 2011 )

- Öğretme ve öğrenmeyi destekleme potansiyeli (Gorgievski, Stroud, Truxaw, \& DeFranco, 2005; Koile \& Singer, 2006; Enriquez, 2010; Phillips, \& Loch, 2011).

- Etkileşime ve işbirlikli öğrenmeye olumlu katkısı (Sneller, 2007; Rawat, Riddick, \& Moore, 2008; Romney, 2010; Ellington, Wilson, \& Nugent, 2011; Jones, \& Sinclair, 2011; Loch, Galligan, Hobohm, \& McDonald, 2011; Mulholland, 2011).

- Öğrenme-öğretme ortamını zenginleştirmesi ve çoklu ortamların kullanımına olanak vermesi (Shurtz, Halling, \& Mckay, 2011; Mills, 2012).

- Bireysel öğrenmeye katkı sağlaması (Stickel, 2009; Mendelsohn, 2012).

- Derslere ilişkin materyallerin kolay erişilebilir ve taşınabilir olması (Shurtz, Halling, \& Mckay, 2011; Dallas, 2012).

- Değerlendirme ve geri bildirim aracı olarak kullanılma potansiyeline sahip olması (Koile, \& Singer, 2006; Tront, \& Prey, 2007; Hawkes, \& Hategekimana, 2009; Kowalski, Kowalski, \& Gardner, 2009; Siozos, Palaigeorgiou, Triantafyllakos, \& Despotakis, 2009; Enriquez, 2010; Gök, 2012).

Tablet bilgisayarların özellikle öğrenciler için öğrenme-öğretme ortamına katkı sağlayabileceği yapılan çalışmalarda ortaya çıkmaktadır. Tüm bu olumlu özelliklerin yanı sıra eğitim amaçı kullanılan her teknolojide olduğu gibi tablet bilgisayarların kullanımına yönelik çeşitli sorunların ortaya çıktığı görülmektedir. Bu sorunlardan bazıları şöyle özetlenebilir:

- Öğrenme, öğretim ve motivasyon açısından yaşanan sorunlar (Lanir, 2012)

- Sağlık yönünden yaşanan ya da yaşanması muhtemel sorunlar (Yan, Hu, Chen \& Lu 2008; Council of Europe, 2011; Rosenfield, 2011; AFP Relaxnews, 2012)

Toplumsal intiyaçlar doğrultusunda yönünü belirleyen teknolojinin yaşamsal açıdan yenilikler getirmeyi amaçlamasına rağmen, yeni teknolojinin uygulanabilirliği toplumun yapısına ve zamana bağı olarak değişmektedir. Özellikle ülkemizde öğrenme-öğretme ortamına yeni giren tablet bilgisayarlara yönelik yapılan çalışmalarda olumlu beklentilere vurgu yapılmasına rağmen, kullanıcılar tarafından yaşanan olumsuzluklara ve bu olumsuzlukların giderilmesine yönelik çalışmaların oldukça sınırlı olduğu görülmektedir. Yapılan çalışmalar incelendiğinde, çalışmaların çoğunlukla ders/konu (matematik, kimya, fizik, vb.) bazında ele alındığı ve daha çok üniversitelerde öğrenim gören küçük gruplar üzerinde yapıldığı görülmektedir. Ayrıca çalışmalarda genel olarak tablet bilgisayarların öğrenmeöğretme ortamına olası katkılarının belirlenmesine daha çok yönelindiği ve karşılaşılan olumsuzluklara ilişkin kapsamlı bir çalışmanın yapılmadığı görülmektedir (örn., Sneller, 2007; Price, \& Simon, 2009; Stickel, 2009; Mendelsohn, 2012; Mills, 2012). Son yıllarda bilişim teknolojilerindeki gelişmelere paralel olarak tablet bilgisayar teknolojisi hızla gelişerek öğrenme-öğretme ortamlarında kullanımı gittikçe yaygınlaşmaktadır. Bu doğrultuda Türkiye'de de öğrenme-öğretme ortamlarına entegrasyonunun sağlanması amaçlanan bu teknolojinin hedeflenen başarıya ulaşması kritik öneme sahiptir. Türk eğitim sistemine büyük katkı getirmesi beklenen bu denli büyük yatııımların ve projelerin başarıya ulaşması için iyi bir planlama yapılması, sürecin değerlendirilmesi ve analiz edilmesi oldukça önemlidir. Bu noktada öğrenme ortamına sunulan yeni teknolojilerin sürece etkilerinin ve varsa aksaklıkların 
belirlenmesi, teknolojinin daha etkin kullanılabilmesi için doğru stratejilerin geliştirilmesine katkı sağlar. Öğrenme ortamında yeni teknoloji kullanan öğretmen ve öğrencilerin sürece ilişkin sorunlarının belirlenmesi ve bu sorunların çözümüne yönelik önerilerinin uygulamaya yansıtılması gerekmektedir. Bunun içinde söz konusu yeni teknolojiyi hali hazırda aktif olarak kullananlar üzerinde araştırmaların yapılması gerekmektedir. Böylelikle kullanıcıların tablet bilgisayarları kullandıkları sırada yaşadıkları sorunlar ve intiyaçları tespit edilerek, gelecekte bu teknolojinin etkin kullanımına yönelik doğru stratejiler geliştirilebilir. Bu çalışmada, ortaöğretim kurumlarında görev yapan öğretmen ve bu kurumlarda öğrenim gören öğrencilerin tablet bilgisayar kullanımı sırasında karşılaştıkları sorunların ve bu sorunlara ilişkin çözüm önerilerinin belirlenmesi amaçlanmıştır. Çalışmanın amacı doğrultusunda tablet bilgisayar kullanımına yönelik öğretmen ve öğrencilerin;

a) yaşadıkları sorunlar nelerdir?

b) yaşadıkları sorunlarla ilgili çözüm önerileri nelerdir?

sorularına yanıt aranmıştır.

\section{Yöntem}

Bu bölümde, araştırmanın modeli, çalışma grubu, verilerin toplanması ve elde edilen verilerin analizi konularında açıklamalar yer almaktadır.

\section{Araştırma modeli}

Araştırma, ortaöğretim kurumlarında görev yapan öğretmen ve bu kurumlarda öğrenim gören öğrencilerin tablet bilgisayar kullanımı sırasında karşılaştıkları sorunların ve bu sorunlara ilişkin çözüm önerilerinin belirlenmesi amacıyla, tarama modelinde tasarlanmıştır. Tarama modelleri, olayları ve olguları geçmişte ya da halen var olduğu şekliyle betimlemeyi amaçlayan yaklaşımlardır (Karasar, 2008). Verilerinin yarı yapılandırımış görüşme formu ile toplandığı çalışmada, veriler içerik analizi ile çözümlenerek kategorize edilmiştir. İçerik analizi, metindeki değişkenleri ölçmek amacıyla, sistematik, tarafsız ve sayısal olarak yapılan bir analizi ifade etmektedir (Wimmer, \& Dominick, 2000, 135-136).

\section{Çalışma Grubu}

FATİH projesi çerçevesinde tüm ortaokul ve ortaöğretim kademelerinde öğrenim gören öğrenciler ve bu kurumlarda görevli öğretmenlere tablet bilgisayar verilmesi planlanmıştır. Bu doğrultuda ülke çapında belirlenen pilot okulların 6. ve 9. sınıflarında öğrenim gören öğrenciler ve bu sınıflarda ders veren öğretmenlere tablet bilgisayarlar 2012 yılı itibariyle verilmeye başlanmıştır. Çalışmanın katıımcıları amaçı örneklem yaklaşımı ile belirlenmiştir. Amaçı̈ı örneklem yaklaşımında temel amaç, araştırmanın konusunu oluşturan kişi, olay ya da durum hakkında ve belirli bir amaç doğrultusunda derinlemesine bilgi toplamaktır (Maxwell, 1996: 71).

Çalışma FATİH projesi kapsamında yer alan ve bu kapsamda tablet bilgisayar dağıtım yapılmış olan 3 farkı türden ortaöğretim kurumunda (Anadolu Lisesi, Fen Lisesi ve Meslek Lisesi) gerçekleştirilmiştir. Bu kapsamda araştırmanın çalışma grubunu, 2012-2013 öğretim yılında FATİH projesi kapsamında tablet bilgisayar dağıtımı yapılan ve bu teknolojiyi derslerinde etkin olarak kullanan ortaöğretim 9. sınıf öğrencileri $(f=286)$ ve bu sınıflarda ders veren öğretmenler $(f=47)$ oluşturmuştur. Çalışmaya katılan öğretmen (Tablo 1) ve öğrencilere (Tablo 2 ) ilişkin bilgiler aşağıda sunulmuştur.

Tablo 1. Araştırmaya Katılan Öğretmenlerin Demografik Özellikleri

\begin{tabular}{|c|c|c|}
\hline Cinsiyeti & Frekans ( $f$ ) & Yüzde (\%) \\
\hline Erkek & 23 & 48,9 \\
\hline Kadın & 24 & 51,1 \\
\hline \multicolumn{3}{|l|}{ Hizmet yılı } \\
\hline$<5$ & 3 & 6,4 \\
\hline $5-10$ & 14 & 29,8 \\
\hline $11-15$ & 19 & 40,4 \\
\hline $15+$ & 11 & 23,4 \\
\hline
\end{tabular}




\begin{tabular}{clcc}
\hline Türk Dili ve Edebiyatı & 6 & 12,8 \\
\hline İngilizce / Almanca & 5 & 10,6 \\
\hline Matematik & 5 & 10,6 \\
\hline Tarih & 5 & 10,6 \\
\hline Fizik & 5 & 10,6 \\
\hline Kimya & 5 & 10,6 \\
\hline Coğrafya & 5 & 10,6 \\
\hline Biyoloji & 4 & 8,5 \\
\hline & Din Kül. ve Ahlak Bil. & 3 & 6,4 \\
\hline & Bilişim Teknolojileri & 2 & 4,3 \\
\hline Toplam & Felsefe & 2 & 4,3 \\
\hline & & $\mathbf{4 7}$ & $\mathbf{1 0 0}$ \\
\hline
\end{tabular}

Tablo 1' de görüldüğü üzere, araştırmaya katılan öğretmenlerin çoğunluğunun $(\% 93,6)$ meslek hayatlarındaki deneyimlerinin 5 yıldan fazla olduğu görülmektedir. Öğretmenlerin branşları dikkate alındığında çalışmanın ortaöğretim kurumunda bulunan branşların çoğunluğunu kapsadığı görülmektedir.

Tablo 2. Araştırmaya Katılan Öğrencilerin Demografik Özellikleri

\begin{tabular}{cccc}
\hline Cinsiyeti & Frekans $(\boldsymbol{f})$ & Yüzde (\%) \\
\hline & Erkek & 145 & 50,7 \\
\hline & Kadın & 141 & 49,3 \\
\hline Toplam & & $\mathbf{2 8 6}$ & $\mathbf{1 0 0}$ \\
\hline
\end{tabular}

Araştırmaya katılan öğrencilerin demografik özellikleri dikkate alındığında cinsiyetler dengeli bir dağıım göstermektedir.

\section{Verilerin Toplanması}

Verilerin toplanması aşamasında, öncelikle araştırmaya katılan öğrenci ve öğretmenler araştırmanın amacı ve beklentilere yönelik olarak hem yazılı hem de sözlü olarak bilgilendirilmişlerdir. Daha sonra, öğrenci ve öğretmenlere çalışmanın amacı doğrultusunda;

"Okulda kullanmış olduğunuz tablet bilgisayarlarda;

a) yaşanılan sorunlar nelerdir?

b) yaşanılan sorunlarla ilgili çözüm önerileriniz nelerdir?"

olmak üzere iki açık uçlu araştırma sorusu yazılı olarak yanıtlanmak üzere verilmiştir. 3 uzman görüşü alınarak araştırmacılarca hazırlanan sorular, öğrenci ve öğretmenlerin düşüncelerini serbestçe ve detaylı bir biçimde ifade etmelerine olanak sağlamak amacıyla yazılı olarak yanıtlanmak üzere verilmiştir. Öğrenciler sınıf ortamında ve araştırmacı gözetiminde yanıtlarını yazııı olarak vermişlerdir. Öğretmenlerin ise ders dışı zamanda, araştırmacı tarafından birebir görüşülerek ve hiçbir şekilde yönlendirme yapılmadan yazılı olarak yanıtlamaları sağlanmıştır.

\section{Verilerin Analiz Edilmesi}

Araştırma katılımcılarının açık uçlu sorulara verdikleri yanıtlardan elde edilen verilerin analizi aşamasında, içerik analiz türlerinden kategorisel analiz ve frekans analizi tekniklerinden yararlanılmışıı. Çalışmanın Kategorisel analiz sürecinde; (1) verilerin kodlanması, (2) kategorilerin oluşturulması, (3) kategorilerin düzenlenmesi (4) bulguların tanımlanması ve yorumlanması aşamaları izlenmiştir (Corbin \& Strauss, 2007). Çalışmada kullanılan frekans analizi ile birimlerin nicel olarak görülme sıklığı ortaya koyularak, belirli bir öğenin yoğunluğu ve önemi belirlenmiştir (Tavşancıl, \& Aslan, 2001). Bu doğrultuda çalışmada, araştırmaya katılan öğrenci $\left(f_{k}, \%_{k}\right)$ ve öğretmenlerin $\left(f_{e}, \%_{e}\right)$ tablet bilgisayarlara yönelik görüşlerinin sıklığını belirtmek amacıyla frekans $(f)$ ve yüzde $(\%)$ değerleri karşılaştırmalı olarak gösterilmiştir. Böylelikle, nitel veriler sayısallaştırılarak verilerin güvenirliği artırııış, yanlılık azaltıımış ve veriler arasında karşılaştırma olanağı sağlanmıştır (Yıldırım ve Şimşek, 
2008). Verilerin analizi sırasında iki araştırmacı verileri ayrı ayrı temalaşırımış, benzer olan temalar kabul edilmiş ve yorumlanmıştır. Ayrıca çalışmada, gerekli görülen yerlerde görüşme metinlerinden doğrudan alıntılar yapılarak araştırma soruları desteklenmiştir. Araştırmadan elde edilen verilerden bazıları olduğu gibi verilerek inandırıılık sağlanmaya çalışılmıştır (Wolcott, 1990). Öğretmen adaylarından yapılan doğrudan alıntılar araşııma etiği çerçevesinde kimlik belirtmemesi için katılımcı isimleri eğitimciler için "e+Sayı", öğrenciler için "k+Sayı" olarak kodlanmıştır.

\section{Bulgular ve Yorumlar}

Araştırmaya katılan öğretmen ve öğrencilerin tablet bilgisayar kullanırken yaşadıkları sorunları, açık uçlu sorulara verdikleri yanıtların analiz edilmesiyle belirlenmiş ve başlıklar altında sunulmuştur. Yapılan analizler sonucunda öğretmen ve öğrencilerin tablet bilgisayarlara ilişkin sorunları; öğrenmeöğretme sürecinde yaşanan sorunlar, donanıma yönelik sorunlar, yazılıma yönelik sorunlar, içeriğe yönelik sorunlar, ergonomi ve sağlık açısından sorunlar olmak üzere beş alt boyutta ele aldıkları ve bu doğrultuda çözüm önerileri sundukları belirlenmiştir. Bu bölümde öğretmen ve öğrencilerin kendi ifadelerine dayalı olarak bu sorunlar alanyazından elde edilen bulgulara göre incelenmiş, yorumlanmış ve değerlendirilmiştir.

\section{1. Öğrenme-öğretme sürecinde tablet bilgisayar kullanımı sırasında yaşanan sorunlar ve bu sorunlara ilişkin çözüm önerileri:}

Tablet bilgisayarlara yönelik öğrenme-öğretme sürecinde öğretmen ve öğrencilerin yaşamış oldukları sorunlar Tablo 3'de sunulmuştur. Bu doğrultuda öğretmen ve öğrencilerin yaşamış oldukları ortak sorunlar* belirlenerek detaylandırımıştır.

\section{Öğretmen}

Tablo 3. Öğrenme-Öğretme Sürecinde Yaşanan Sorunlar

\begin{tabular}{llcc}
\hline & & fe & \%e \\
\hline 1. & Tablet bilgisayarlar öğrenciler tarafından amacı dışında kullanılıyor.* & 19 & 40,4 \\
\hline 2. & Tablet bilgisayar sınıftaki çalışma ortamını olumsuz etkiliyorlar.* & 17 & 36,2 \\
\hline 3. & Tablet bilgisayarlar etkileşimi ve katıımı azaltıyor.* & 16 & 34,0 \\
\hline 4. & $\begin{array}{l}\text { Tablet bilgisayar üzerinde işlem yapmak (not almak, çizim yapmak, } \\
\text { vb.) için uygun değildir.* }\end{array}$ & 16 & 34,0 \\
\hline 5. & $\begin{array}{l}\text { Tablet bilgisayarlar derse ilişkin faaliyetlerde zaman kaybına neden } \\
\text { oluyor.* }\end{array}$ & 15 & 31,9 \\
\hline 6. & Öğrenciler tablet bilgisayarlara odaklanıp, dersten uzaklaşıyor. & 15 & 31,9 \\
\hline 7. & $\begin{array}{l}\text { Öğrencilerin ders esnasında tablet bilgisayarlarında ne yaptıklarını } \\
\text { göremiyorum. }\end{array}$ & 15 & 31,9 \\
\hline 8. & Tablet bilgisayar basılı materyallere olan ilgiyi azaltıyor.* & 11 & 23,4 \\
\hline
\end{tabular}

\section{Öğrenci}

\begin{tabular}{lllc}
\hline & \multicolumn{1}{c}{} & \multicolumn{1}{c}{$\mathbf{\%}$} \\
\hline 1. & $\begin{array}{l}\text { Tablet bilgisayarlar amacı dışında kullanılıyor (örn. Müzik dinlemek, } \\
\text { film izlemek, vd. ).* }\end{array}$ & 101 & 35,3 \\
\hline 2. & Tablet bilgisayar sınıftaki çalışma ortamını olumsuz etkiliyor.* & 91 & 31,8 \\
\hline 3. & Tablet bilgisayarlar derslerdeki etkileşimi ve katılımı azaltıyor.* & 88 & 30,8 \\
\hline 4. & $\begin{array}{l}\text { Tablet bilgisayarlar derse ilişkin faaliyetlerde zaman kaybına neden } \\
\text { oluyor.* }\end{array}$ & 70 & 24,5 \\
\hline 5 & Tablet bilgisayar derste dikkatimi dağıtıyor. & 66 & 23,1 \\
\hline 6. & $\begin{array}{l}\text { Tablet bilgisayar üzerinde işlem yapmak (not almak, çizim yapmak, } \\
\text { vb.) için uygun değildir.* }\end{array}$ & 60 & 21,0 \\
\hline
\end{tabular}


\begin{tabular}{llrr}
\hline 7. & Tablet bilgisayar basılı materyallere olan ilgiyi azaltıyor.* & 48 & 16,8 \\
\hline
\end{tabular}

Not : * İşaretli sorunlar öğretmen ve öğrenciler için ortak sorunlardır.

Öğrenme-öğretme sürecinde tablet bilgisayarların kullanımına yönelik yaşanan sorunların önem sıraları öğretmen ve öğrenciler açısından farklılık gösterse de çoğu sorununun ortak olduğu görülmektedir. Bu süreçte tablet bilgisayarların amacı dışında kullanılmasının öğretmen ve öğrenciler için en önemli sorun olarak görüldüğü belirlenmiştir $\left(f_{\mathrm{e}}=19, \%_{\mathrm{e}}=40.4 ; f_{\mathrm{k}}=101, \% \mathrm{k}=35.3\right)$. Bir diğer önemli sorun olarak da tablet bilgisayarların sınıftaki çalışma ortamını olumsuz etkilemesidir $\left(f_{\mathrm{e}}=17, \quad \%_{\mathrm{e}}=36.2\right.$; $f_{k}=91, \% \mathrm{k}=31.8$ ). Genellikle tablet bilgisayarların amacı dışında kullanılmasından kaynaklı olduğu belirtilen bu sorunun sınıf içindeki etkileşimi ve katıııı da olumsuz etkilediği görülmektedir $\left(f_{\mathrm{e}}=16, \%_{\mathrm{e}}=34.0 ; f_{\mathrm{k}}=88, \% \mathrm{k}=30.8\right)$. Daha çok etkileşim ve sınıf yönetimi ile ilişkilendirilebilecek bu sorunların dışında tablet bilgisayarların derse ilişkin faaliyetlerde zaman kaybına neden olması $\left(f_{\mathrm{e}}=15, \%_{\mathrm{e}}=31.9 ; f_{\mathrm{k}}=70, \%_{\mathrm{k}}=24.5\right)$ ve işlem yapılması (not almak, çizim yapmak, vb.) için uygun olmamasının da $\left(f_{\mathrm{e}}=16, \% \mathrm{e}=34.0 ; f_{\mathrm{k}}=60, \% \mathrm{k}=21.0\right)$ öğretmen ve öğrenciler için ortak sorunlar olduğu belirlenmiş̧ir. Öğretmen ve öğrenciler için bir diğer ortak sorun ise özellikle öğretmenlerin sıklıkla vurgulamış oldukları tablet bilgisayarların basılı materyallere olan ilgiyi azaltması $\left(f_{\mathrm{e}}=11, \%_{\mathrm{e}}=23.4\right.$; $\left.f_{k}=48, \% k=16.8\right)$ yönündeki kaygı ifadeleridir. Bu soruna yönelik olarak, özellikle öğretmenlerin kaygılarının öğrencilerden daha çok olmasının temel gerekçesi, öğretmenlerin basılı materyallere daha alışık olması ve bu materyaller üzerinde işlem yapma yeteneklerinin daha fazla gelişmiş olmasından kaynaklı olduğu söylenebilir. Ayrıca Dağtaş (2013)'ın çalışmasında belirttiği gibi öğretmenlerin büyük bir çoğunluğunun basılı sayfadan okuma ve öğrenmenin daha kolay, kalıcı olduğu ve basıllı sayfa üzerinde not alma, altını çizme gibi davranışların kalem aracılığıyla daha kolay yapılabildiği ve bunların okuma sürecine katkıda bulunduğu algısı da belirtilen bu sorunun nedeni olarak görülebilir.

Yapılan çalışmada öğretmenler öğrencilerden farklı olarak öğrencilerin ders sırasında tablet bilgisayarlara odaklanıp, dersten uzaklaşımasını önemli bir sorun olarak görmektedirler $\left(f_{\mathrm{e}}=15, \%_{\mathrm{e}}=31.9\right)$. Özellikle bu sorunun öğrencilerin tablet bilgisayarlarında ne yaptıklarını göremiyor olmalarından kaynaklandığı öğretmenler tarafından $\left(f_{\mathrm{e}}=15, \% \mathrm{o}=31.9\right)$ ifade edilmektedir. Öğrencilerin kullanmış olduğu tablet bilgisayarların özellikle ders sırasında öğretmen tarafından kontrol edilememesinden kaynaklı olduğu belirtilen bu sorunların sınıf yönetimi, etkileşim ve katılımı da olumsuz etkilediği öğretmenler tarafından sıklıkla vurgulanmaktadır. Çalışmaya katılan öğrenciler ise öğretmenlerden farklı olarak tablet bilgisayarın derste dikkat dağımasına neden olduğu ve bunun bir sorun teşkil ettiğini belirtmektedirler $\left(f_{k}=66, \% k=23.1\right)$. Özellikle bu sorunun tablet bilgisayarların amacı dışında kullanılmasıyla ilgili olduğu söylenebilir. Bu duruma yönelik olarak Lanir (2012) tarafından yapılan araştırmada da öğrencilerin öğretmenlerine odaklanması gerekirken tablet bilgisayarlarından e-posta, oyunlar ve web sitelerine odaklandıkları yönünden bir sorun tespiti yapılmıştır. Yapılan çalışmada ayrıca, K12 öğretmenlerinin büyük çoğunluğunun (\% 87) "bugünün dijital teknolojilerinin kolayca dikkati dağıır nesil yaratıyor" olduğuna inandıkları belirlenmiştir (Lanir, 2012).

Öğretmen ve öğrencilerin tablet bilgisayarların öğrenme-öğretme ortamına yönelik belirtmiş oldukları sorunlara genel olarak bakıldığında, bir sorunun diğer sorunların da ortaya çıkmasına neden olabildiği görülmektedir. Özellikle tablet bilgisayarların amacı dışında kullanılması, öğrencinin dersten kopmasına yol açabilmekte ve bu durumda sınıf içi çalışma ortamı olumsuz etkilenebilmektedir. Bu çerçevede felsefe öğretmeni (e33), "Ben tahtada ders işlerken, bazı öğrencilerde tabletleriyle uğraşıyorlar. Her ne kadar uyarsam da bir süre sonra tabletleriyle ilgilenmeye devam ediyorlar" şeklinde sınıf içinde yaşamış olduğu sorunu belirtmektedir. 9. sınıf öğrencisi (k92) "Tablet bilgisayar oyun oynamak ve film izlemek için oldukça iş̧ime yarıyor. Biraz daha hızlı olsaydı daha iyi olurdu." ve bir diğer öğrencinin (k113) "Eğer oyunum yarım kaldıysa ders sirasında hep aklım oyunda kalıyor. Uygun ortam bulduğumda da derste oyunuma devam ediyorum." şeklindeki ifadesi tablet bilgisayarların amacı dışında kullanılmasının öğretme-öğrenme sürecine olumsuz yansıdığını göstermektedir. Sorunların bir diğer kaynağı olarak da öğrenme-öğretme sürecinde tablet bilgisayarlar konusunda öğretmen ve öğrencilerin yeteri kadar bilgi ve beceri sahibi olmamalarından kaynaklı olduğu görülmektedir. Bu çerçevede coğrafya öğretmeni (e8), "Daha önce hiç tablet kullanmadım ve bu konuda öğrenciler benden çok daha tecrübeliler." şeklinde durumu ifade etmektedir. Buna ilişkin olarak (k3) "Tablet bilgisayarlar oyun oynamak, internete girmek ve film izlemek dışında bir işime yaramıyor. Derste 
tableti hangi amaçla kullanacağım?"şeklindeki ifadesi ise tablet bilgisayarların ders amacı ile kullanımı konusunda yeteri kadar bilgi sahibi olmadığını göstermektedir. Bu çerçevede öğretmen ve öğrencilerin tablet bilgisayarların öğrenme-öğretme sürecinde yaşamış oldukları sorunların çözülmesi ve gerekli önlemlerin alınması önemli bir unsur olarak görülmektedir. Bu doğrultu tablet bilgisayarları derslerinde etkin olarak kullanan öğretmen ve öğrencilerin öğrenme-öğretme sürecinde yaşanan sorunlara ilişkin olarak;

- Tablet bilgisayarların amacı dışında kullanılmasının engellenmesi gerektiği $\left(f_{\mathrm{e}}=19, \%_{\mathrm{e}}=40.4\right.$; $f_{\mathrm{k}}=101, \% \mathrm{k}=35.3$ ),

- Etkileşimli tahta-tablet bilgisayarlar ve tablet bilgisayarların birbiri arasındaki etkileşim sağlanması gerektiği $\left(f_{\mathrm{e}}=18, \%_{\mathrm{e}}=38.3 ; f_{\mathrm{k}}=95, \%_{\mathrm{k}}=33.2\right)$,

- Tablet bilgisayarların öğrenme öğretme ortamında etkin kullanılabilmesi için eğitimlerin verilmesi gerektiği $\left(f_{\mathrm{e}}=16, \%_{\mathrm{e}}=34.0 ; f_{\mathrm{k}}=65, \% \mathrm{k}=22.7\right)$,

- Tablet bilgisayarların etkin kullanımına yönelik yardımcı alan uzmanı kişilerin görevlendirilmesi gerektiği $\left(f_{\mathrm{e}}=15, \%_{\mathrm{e}}=31.9 ; f_{\mathrm{k}}=61, \%_{\mathrm{k}}=21.3\right)$ ve

öğretmenler öğrencilerinden farklı olarak,

- Tablet bilgisayarların öğretmenler tarafından kontrol edilebilmesinin sağlanması gerektiği $\left(f_{e}=15, \% e=31.9\right)$

yönünde çözüm önerileri sunmaktadırlar. Çalışmaya katılan öğretmen ve öğrenciler bu öneriler dikkate alındığında öğrenme-öğretme ortamında tablet bilgisayarların daha verimli bir biçimde kullanılabileceğini belirtmektedirler.

\section{Tablet bilgisayarlarda donanıma yönelik sorunlar ve bu sorunlara ilişkin çözüm önerileri:}

Tablet bilgisayarlara yönelik öğrenme-öğretme ortamında öğretmen ve öğrencilerin donanıma ilişkin yaşamış oldukları sorunlar Tablo 4'de sunulmuştur.

\section{Öğretmen}

Tablo 4. Tablet Bilgisayarlarda Donanıma İlişkin Sorunlar

1. Diğer cihazlarla (internet, cihaz-bilgisayar bağlantısı vs.) bağlantı sorunları yaşıyorum.*

fe \%e

$\begin{array}{lll}17 & 36,2\end{array}$

\begin{tabular}{lll}
\hline 2. Tablet bilgisayar yavaş çalışıyor ve tutukluk yapıyor.* & 17 & 36,2
\end{tabular}

3. Şarjının çabuk bitmesi ve kısa sürede şarj edilememesi sorun yaratıyor.*

$16 \quad 34,0$

4. Çevre birimlerinin çalışmasında sorunlar yaşıyorum (örn. Hoparlör, giriş ve çıkış birimleri, vb. ).*

$16 \quad 34,0$

5. Teknik sorunların kısa sürede çözülememesi (servis / Servis elemanları en kısa zamanda gelmemesi) sorun yaratıyor.*

$14 \quad 29,8$

\section{Öğrenci}

\begin{tabular}{|c|c|c|}
\hline & $f_{\mathrm{k}}$ & $\%$ \\
\hline $\begin{array}{l}\text { 1. Diğer cihazlarla (internet, cihaz-bilgisayar bağlantısı vs.) bağlantı } \\
\text { sorunları yaşıyorum.* }\end{array}$ & 113 & 39,5 \\
\hline 2. Tablet bilgisayar yavaş çalışıyor ve tutukluk yapıyor.* & 92 & 32,2 \\
\hline $\begin{array}{l}\text { 3. Şarjının çabuk bitmesi ve kısa sürede şarj edilememesi sorun } \\
\text { yaratıyor.* }\end{array}$ & 91 & 31,8 \\
\hline $\begin{array}{l}\text { 4. Çevre birimlerinin çalışmaması (örn. Hoparlör, giriş birimleri vb. ) } \\
\text { sorun yaratıyor.* }\end{array}$ & 72 & 25,2 \\
\hline $\begin{array}{l}\text { 5. Teknik sorunların kısa sürede çözülememesi (servis / Servis elemanları } \\
\text { en kısa zamanda gelmemesi) sorun yaratıyor.* }\end{array}$ & 49 & 17,1 \\
\hline
\end{tabular}

Not : * İşaretli sorunlar öğretmen ve öğrenciler için ortak sorunlardır. 
Tablet bilgisayar dağıtılan 286 öğrenci ve 47 öğretmen üzerinde gerçekleştirilen çalışmadan elde edilen veriler, tablet bilgisayarlara yönelik donanımsal sorunların ilk olarak dağııılığı aşama başladığını göstermektedir. Bu doğrultuda tablet bilgisayarların ilk dağıtımından sonra öğretmenlerin $\left(f_{\mathrm{e}}=7, \% \mathrm{k}=14.9\right)$ ve öğrencilerin $\left(f_{\mathrm{k}}=42, \% \mathrm{k}=14.7\right)$ bir kısmının tabletlerindeki donanımsal sorunlardan dolayı iade ettikleri belirlenmiştir. Öğrenci ve öğretmenlerin çalışmaya verdikleri yanıtlar ve okul idarelerinden alınan verilere göre belirlenen bu sayllar, tablet bilgisayarların büyük bir çoğunluğunun üretici firmadan kaynaklı olarak hatalı teslim edildiğini göstermektedir. Bu doğrultuda iade edilen tabletlerin tamir edilerek ya da yenisi verilerek de 1 hafta ile 3 hafta arasında kullanıclara iade edildiği belirlenmiş̧ir. Yapılan çalışma sonucunda tablet bilgisayaralar da donanıma ilişkin sorunlar incelendiğinde öğretmen ve öğrenciler için önem sıraları farklı olsa da tüm sorunların ortak olduğu görülmektedir.

Yapılan çalışma sonucunda tablet bilgisayarların diğer cihazlarla (internet, cihaz-bilgisayar bağlantısı vs.) bağlantı sorunları yaşanması $\left(f_{\mathrm{e}}=17, \%_{\mathrm{e}}=36.2 ; f_{\mathrm{k}}=113, \% \mathrm{k}=39.5\right)$, çevre birimlerinin çalışmaması $\left(f_{e}=16, \%_{\mathrm{e}}=34.0 ; f_{\mathrm{k}}=72, \%_{\mathrm{k}}=25.2\right)$, şarjının çabuk bitmesi ve kısa sürede şarj edilememesine $\left(f_{\mathrm{e}}=16, \%_{\mathrm{e}}=28.6 ; f_{\mathrm{k}}=91, \% \mathrm{k}=31.8\right)$ yönelik sorunların daha çok uzman kişilerce çözülebilecek sorunlar olduğu görülmektedir. Ayrıca tablet bilgisayarlardaki teknik sorunların kısa sürede çözülememesinden $\left(f_{\mathrm{e}}=14, \%_{\mathrm{e}}=29.8 ; f_{\mathrm{k}}=49, \%_{\mathrm{k}}=17.1\right)$ kaynaklı olarak uzun süre tabletlerini kullanmamalarının da önemli bir sorun olduğu belirlenmiştir. Tablet bilgisayarlara yönelik belirlenen bir diğer sorun ise tablet bilgisayarların yavaş çalışması ve tutukluk yapmasıdır $\left(f_{\mathrm{e}}=17, \%_{\mathrm{e}}=36.2 ; f_{\mathrm{k}}=92, \% \mathrm{k}=32.2\right)$. Donanım ya da kullanılan yazılım ile ilgili olabileceği belirtilen bu sorunun öğrenme-öğretme materyallerinin etkin çalışmasını engellediği sıklıkla vurgulanmaktadır. Genel olarak tablet bilgisayarlarda donanıma yönelik sorunların daha çok uzman kişilerce çözülebilecek sorunlar olduğu görülmektedir. Özellikle bu sorunların teknik sorunlar olduğu ve kullanıcıların çok müdahale edebilecekleri sorunlar olmadığı söylenebilir.

Tablet bilgisayarlarda meydana gelen herhangi bir donanımsal sorun çözülemediği takdirde dersin bu cihazlarla işlenmesi durumunda kullanıının eğitim süreci sekteye uğrayabilmekte ve özelliklede bu olumsuzluktan öğrencilerin etkilendiği görülmektedir. Bu soruna yönelik olarak coğrafya öğretmeni (e43) ise "bazen ders ile ilgili bir haritanın tablet bilgisayarlardan takip edilmesini istiyorum ancak birkaç ögrencinin tablet bilgisayarında sorun yaşandığında bu öğrenciler dersi etkileşimli tahtadan takip etmek durumunda kalıyorlar. Bu durumda da harita üzerinde gezinemiyorlar ve işlem yapamıyorlar" şeklinde donanımsal sorunların sürece olumsuz etkisini belirtmektedir. 9. Sınıf öğrencisi (k11) ise "tablet bilgisayarımda sorun yaşandığında dersi arkadaşımın tabletinden takip etmek zorunda kalıyorum. O zamanda kendi tabletim üzerinde işlem yapamadığımdan not ve çizimleri defterime yapmak zorunda kalıyorum. "şeklinde yaşamış olduğu sorunu belirtmektedir. Çalışma sonucunda elde edilen veriler donanımsal sorunların çözümünde daha çok teknik bilginin gerekli olduğunu göstermektedir. Bu noktada da öğretmen ve öğrencilerin tablet bilgisayarların kullanımı ile birlikte süreç içerisinde meydana gelebilecek olası donanımsal sorunlara müdahale edebilecek nitelikte eğitimlerin verilmesi ve sorunlarla baş edebilme yeterliliklerinin kazandırılması gerekliliği ortaya çıkmaktadır. Tablet bilgisayarları derslerinde etkin olarak kullanan öğretmen ve öğrencilerin öğrenmeöğretme sürecinde tablet bilgisayarlarda donanıma yönelik yaşanan sorunlara ilişkin olarak;

- Tablet bilgisayarlarda yaşanan teknik sorunların çözümünde öğretmen ve öğrencilere teknik destek sağlanması gerektiği $\left(f_{\mathrm{e}}=21, \% \mathrm{o}=44.7 ; f_{\mathrm{k}}=103, \% \mathrm{k}=36.0\right)$,

- Tablet bilgisayarlarda yaşanan donanımsal sorunların kısa zamanda çözümünün sağlanması gerektiği $\left(f_{\mathrm{e}}=16, \%_{\mathrm{e}}=34.0 ; f_{\mathrm{k}}=77, \% \mathrm{k}=26.9\right)$,

- Tablet bilgisayarların donanımsal olarak zamanla yenilenmesi gerektiği ( $f_{\mathrm{e}}=14, \%_{\mathrm{e}}=29.8$; $f_{\mathrm{k}}=76, \% \mathrm{k}=26.6$ ),

- Tablet bilgisayarlara yönelik teknik bilgileri de kapsayacak nitelikte eğitimlerin verilmesi gerektiği $\left(f_{\mathrm{e}}=14, \% \mathrm{e}=29.8 ; f_{\mathrm{k}}=41, \% \mathrm{k}=14.3\right)$

yönünde çözüm önerileri sunmaktadırlar. Çalışmaya katılan öğretmen ve öğrenciler bu öneriler dikkate alındığında donanımsal sorunların kısa sürede çözülerek sürecin olumsuz etkilenmesinin önlenebileceğini belirtmektedirler. 


\section{Tablet bilgisayarlarda yazılıma yönelik sorunlar ve bu sorunlara ilişkin çözüm önerileri:}

Tablet bilgisayarlara yönelik öğrenme-öğretme ortamında öğretmen ve öğrencilerin yazılıma ilişkin yaşamış oldukları sorunlar Tablo 5'de sunulmuştur.

Öğretmen

Tablo 5. Tablet Bilgisayarlarda Yazilıma İlişkin Sorunlar

\begin{tabular}{|c|c|c|c|}
\hline & & $f_{\mathrm{e}}$ & $\%$ e \\
\hline & $\begin{array}{l}\text { Tablet bilgisayarda yazılım kısıtlamaları (program, eklenti, yazılım, } \\
\text { vb.) etkili kullanımı engelliyor.* }\end{array}$ & 20 & 42,6 \\
\hline 2. & $\begin{array}{l}\text { Tablet bilgisayarda bulunan kendi yazılımlarının dışında farklı } \\
\text { yazııımlara ihtiyaç duyuyorum.* }\end{array}$ & 18 & 38,3 \\
\hline & $\begin{array}{l}\text { Kişisel bilgilerimin gizliliği ve güvenliği ile ilgili tedirginlik } \\
\text { duyuyorum.* }\end{array}$ & 16 & 34,0 \\
\hline & $\begin{array}{l}\text { Tablet bilgisayarlar yüksek sistem gerektiren programlar için yetersiz } \\
\text { kalıyor.* }\end{array}$ & 14 & 29,8 \\
\hline
\end{tabular}

\section{Öğrenci}

f $\% \mathbf{k}$

1. Tablet bilgisayarda yazılım kısıtlamaları (program, eklenti, yazılım, vb.) etkili kullanımı engelliyor.* $128 \quad 44,8$

2. Tablet bilgisayarlarda bulunan kendi yazılımlarının dışında farklı yazilımlara intiyaç duyuyorum.*

$109 \quad 38,1$

3. Tablet bilgisayarlar yüksek sistem gerektiren programlar için yetersiz kalıyor.*

4 Kişisel bilgilerimin gizliliği ve güvenliği ile ilgili tedirginlik

$$
\text { duyuyorum.* } \quad 47 \quad 16,4
$$

Not : * İşaretli sorunlar öğretmen ve öğrenciler için ortak sorunlardır.

Öğrenme-öğretme sürecinde tablet bilgisayarlarda yazılıma ilişkin sorunlar incelendiğinde öğretmen ve öğrenciler için tüm sorunların ortak olduğu görülmektedir. Çalışma sonucunda tablet bilgisayarlardaki kısıtlamaların (program, eklenti, vb.) etkili kullanımını engellemesi öğretmen ve öğrenciler için en önemli yazılımsal sorun olarak görüldüğü belirlenmiştir $\left(f_{\mathrm{e}}=20, \%_{\mathrm{e}}=42.6 ; f_{\mathrm{k}}=128, \% \mathrm{k}=44.8\right)$. Çalışmaya katılan öğretmenlerinde önemli bir sorun olarak gördükleri bu sınırlandırmaların, diğer sorunlara oranla öğrenciler içinde yüksek düzeyde sorun teşkil etmesi dikkat çekicidir. Bu çerçevede öğretmen ve öğrencilerin tablet bilgisayarlarda yaşanan en önemli sorunlardan biri olarak görülen yazılım kısıtlamalarının tablet bilgisayarların etkin kullanımında büyük bir engel olduğu söylenebilir. Aynı zamanda bu kısıtlamaların tablet bilgisayarlarda bulunan yazılımların dışında farklı yazılımlara intiyaç duyulması $\left(f_{\mathrm{e}}=18, \% \mathrm{o}=38.3 ; f_{\mathrm{k}}=109, \% \mathrm{k}=38.1\right)$ sorunlarının giderilmesine de engel olduğu görülmektedir. Tablet bilgisayarlarda yaşanan bir diğer sorun olarak da yüksek sistem gerektiren programlar için tablet bilgisayarların yetersiz kalmasıdır $\left(f_{\mathrm{e}}=14, \%_{\mathrm{e}}=29.8 ; f_{\mathrm{k}}=107, \%_{\mathrm{k}}=37.4\right)$. Bu sorun yazılımsal olabileceği gibi donanımın intiyaç duyulan program için yetersiz kalmasından da kaynaklı olabilir. Dolayısıyla tablet bilgisayarlara uygun intiyaç duyulan yazılımların kullanıcıları sunulması gereklidir. Çalışmada öğretmen ve öğrencilerin belirttikleri bir diğer sorun ise kişisel bilgilerinin gizliliğinin ve güvenliğinin sağlanamayacağı yönündeki tedirginlikleridir $\left(f_{\mathrm{e}}=16, \% \%_{\mathrm{e}}=34.0\right.$; $\left.f_{k}=47, \% k=16.4\right)$. Bu soruna ilişkin kullanıcılara özel olarak tanımlanan tabletlerde yaptıkları işlemlerin takip edilebilir olmasının, tablet kullanımını sınırlandırdığı belirtilmektedir. Ayrıca çalışmada tablet bilgisayarların ortak bir ağ üzerinden bağlanması ve bu nedenle kişisel bilgilerin güvenliğinin sağlanamayabileceği yönündeki endişelerin sıklıkla vurgulandığı görülmektedir.

Yapılan çalışma sonucunda elde edilen veriler öğrenme-öğretme sürecinde öğretmen ve öğrencilerin yazılımsal sorunlarla sıklıkla karşılaştıkları ve bu sorunların ders sürecini olumsuz etkilediği görülmektedir. Bu noktada tarih öğretmeni (e33), "bilgisayarımda hazırlamış olduğum sunum tablet bilgisayarda çalışmıyor. Eklenti hatası geliyor ancak kısıtlamalardan dolayı da eklenti yüklenemiyor", 
İngilizce öğretmeni (e46) ise "tablet bilgisayarda Office programlarının yüklenmesi gerekmekte. Dosyaları görüntülemekte ve düzeltmekte zorluk çekiyorum " şeklinde yaşamış oldukları yazılımsal sorunu ifade etmektedir. 9. Sınıf öğrencisi (k338) ise "tablet bilgisayarlara hiç bir şey yüklenmiyor. Dolayısılla tablet bilgisayar gibi kullanamıyorum. Her şey sınırlandırılmıs durumda ve dersle ilgili olsa da olmasa da yazlım indirmeye veya yüklemeye izin vermiyor." şeklinde yaşamış olduğu sorunu belirtmektedir. Çalışma sonucunda elde edilen veriler tablet bilgisayarlardaki yazılımsal sorunların özellikle mevcut kısıtlamalardan kaynaklı olduğu ve bundan dolayı da sorunlara müdahalenin zorlaştığını göstermektedir. Bu noktada da öğretmen ve öğrencilerin süreç içerisinde meydana gelebilecek olası yazılımsal sorunlara müdahale edebilecek nitelikte eğitimlerin verilmesi veya okullarda alanında uzman yetkili kişilerin görevlendirilmesi gerekliliği ortaya çıkmaktadır. Tablet bilgisayarları derslerinde etkin olarak kullanan öğretmen ve öğrencilerin öğrenme-öğretme sürecinde tablet bilgisayarlarda yazilımsal sorunlara ilişkin olarak;

- Tablet bilgisayarlarda yazılım kısıtlamalarının kaldırıması gerektiği $\left(f_{\mathrm{e}}=22, \%_{\mathrm{e}}=46.8 ; f_{\mathrm{k}}=176\right.$, $\%$ k $=61.5$ ),

- Tablet bilgisayarlarda intiyaç duyulan yazılımların yüklenmesine izin verilmesi gerektiği $\left(f_{e}=20\right.$, $\%_{\mathrm{e}}=42.6 ; f_{\mathrm{k}}=156, \% \mathrm{k}=54.5$ ),

- Tablet bilgisayarlarda yaşanan yazılımsal sorunların kısa zamanda çözümünün sağlanması gerektiği $\left(f_{e}=18, \% e=38.3 ; f_{k}=103, \% k=36.0\right)$,

- Tablet bilgisayarlarda yazilımsal olarak zamanla güncellenmesi gerektiği $\left(f_{\mathrm{e}}=13, \%_{\mathrm{e}}=27.7\right.$; $f_{k}=73, \% \mathrm{k}=25.5$ ),

- Tablet bilgisayarlarda yaşanan yazılımsal sorunların çözümünde öğretmen ve öğrencilere destek sağlanması gerektiği $\left(f_{\mathrm{e}}=13, \% \mathrm{o}=27.7 ; f_{\mathrm{k}}=71, \%_{\mathrm{k}}=24.8\right)$

doğrultusunda çözüm önerileri sunmaktadırlar. Çalışmaya katılan öğretmen ve öğrenciler bu öneriler dikkate alındığında öğrenme-öğretme ortamında yazılımsal sorunların kısa sürede çözümlenebileceğini belirtmektedirler.

\section{Tablet bilgisayarlarda ders içeriklerine yönelik sorunlar ve bu sorunlara ilişkin çözüm önerileri:}

Tablet bilgisayarlara yönelik öğrenme-öğretme ortamında öğretmen ve öğrencilerin içeriğe ilişkin yaşamış oldukları sorunlar Tablo 6'da sunulmuştur.

\section{Öğretmen}

Tablo 6. Tablet Bilgisayarlarda Ders İçeriklerine İlişkin Sorunlar

\begin{tabular}{llrrr}
\hline 1. & $\begin{array}{l}\text { Tablet bilgisayarlar üzerinden bazı yararlı site ve içeriklere } \\
\text { erişemiyorum.* }\end{array}$ & \multicolumn{1}{c}{ fee } \\
\hline 2. & $\begin{array}{l}\text { Tablet bilgisayarda kullanabileceğim derse yönelik içerik bulmakta } \\
\text { zorlanıyorum.* }\end{array}$ & 53,2 \\
\hline 3. & $\begin{array}{l}\text { Tablet bilgisayar üzerinde materyal hazırlamakta ve düzenlemekte } \\
\text { zorluk yaşıyorum.* }\end{array}$ & 48,9 \\
\hline
\end{tabular}

\section{Öğrenci}

\begin{tabular}{|c|c|c|c|}
\hline & & $f_{k}$ & $\%$ \\
\hline$\overline{1 .}$ & $\begin{array}{l}\text { Tablet bilgisayar üzerinden bazı yararlı site ve içeriklere } \\
\text { erişemiyorum.* }\end{array}$ & 172 & 60,1 \\
\hline 2. & $\begin{array}{l}\text { Tablet bilgisayarda kullanabileceğim derse yönelik içerik bulmakta } \\
\text { zorlanıyorum.* }\end{array}$ & 101 & 35,3 \\
\hline 3. & $\begin{array}{l}\text { Tablet bilgisayarlar üzerinde } \\
\text { düzenlemekte zorluk yaşıyorum.* }\end{array}$ & 76 & 26,6 \\
\hline
\end{tabular}

Not : * İşaretli sorunlar öğretmen ve öğrenciler için ortak sorunlardır. 
Öğrenme-öğretme sürecinde tablet bilgisayarlarda derse yönelik içeriklere ilişkin sorunlar incelendiğinde öğretmen ve öğrenciler için tüm sorunların ortak olduğu görülmektedir. Çalışma sonucunda tablet bilgisayarlardaki yazılımsal kısıtlamaların yanı sıra tablet bilgisayarlar üzerinden bazı yararlı site ve içeriklere erişilememesinin $\left(f_{\mathrm{e}}=25, \%_{\mathrm{e}}=53.2 ; f_{\mathrm{k}}=172, \% \mathrm{k}=60.1\right)$ öğretmen ve öğrenciler açısından içeriğe yönelik en önemli sorun olduğu görülmektedir. Bu soruna yönelik olarak özellikle öğretmen ve öğrencilerin önemli bir sorun olarak gördükleri bu kısıtlamaların sınırlandırılması gerektiği sıkıkla vurgulanmaktadır. Keser ve Çetinkaya (2013) tarafından etkileşimli tahtalar üzerinde yapılan çalışmada da benzer sonuç elde edilmiş ve etkileşimli tahtalardaki yazılıma yönelik sınırlamaların öğretmen ve öğrenciler için oldukça önemli bir sorun olduğu belirlenmiştir. Bu doğrultuda tablet bilgisayarların ve etkileşimli tahtaların aynı ağ yapısını kullanmasından dolayı özellikle internet ortamındaki kısıtlamaların tekrar gözden geçirilip düzenlenmesi gerekliliği ortaya çıkmaktadır. Tablet bilgisayarlarda kullanılabilecek derse yönelik içeriklerin yetersiz $\left(f_{\mathrm{e}}=23, \%_{\mathrm{e}}=48.9 ; f_{\mathrm{k}}=101, \% \mathrm{k}=35.3\right)$ olmasının öğretmenler ve öğrenciler için önemli sorunlardan biri olduğu görülmektedir. Bu sorun ile ilişkili olarak özellikle derslere yönelik içerik geliştirilmesi ve bu içeriklerin tablet bilgisayarlarla birlikte sunulması gerekliliği kullanıcılar tarafından sıklıkla vurgulanmışıı. Tablet bilgisayarlarda içeriğe yönelik bir diğer sorunda tablet bilgisayarlarda ders materyalleri üzerinde düzenlemeler yapılmasında $\left(f_{e}=20, \% e=42.6 ; f_{k}=76, \% k=26.6\right)$ öğretmen ve öğrencilerin zorluk yaşamasıdır. Genel olarak bu sorunun kaynağı olarak öğretmen ve öğrencilerin tablet bilgisayar kullanımı konusundaki yeterliliklerinin de önemli olduğu söylenebilir.

Çalışma sonucunda elde edilen veriler öğrenme-öğretme sürecinde öğretmen ve öğrencilerin tablet bilgisayarlarda kullanabilecekleri içeriklere ilişkin sorunlar yaşadıkları ve özellikle internete yönelik kısıtlamaların bu sorunların giderilmesini kısıtladığı görülmektedir. Bu noktada tarih öğretmeni (e37), "tablet bilgisayarlarda kullanabileceğim türden derse yönelik materyal bulamıyorum. Bulsam da sınırlandırmalardan dolayı ilgili sayfaya giremiyorum ya da indiremiyor" şeklinde yaşamış olduğu sorunu belirtmektedir. Konu ile ilgili 9. sınıf öğrencisi (k1) ise "tablet bilgisayarlarda çoğu siteye giremiyorum. Bu siteler ders ile ilgili de olsa sistem izin vermiyor. Bu durumda internet üzerinden bilgi almak istediğimde sürekli kısıtlamalarla karşı karşıya kalıyorum" şeklinde yaşamış olduğu sorunu ifade etmektedir. Ayrıca çalışma sonucunda elde edilen veriler özellikle tablet bilgisayarlarda kullanılabilecek nitelikte uygun materyal bulunması ve hazırlanılması konusunda sorun yaşanıldığını göstermektedir. Özellikle öğretmenlerin yaşamış oldukları bu sorunların giderilmesinde, hizmetiçi eğitim gereksinimleri de ortaya çıkmaktadır. Bu noktada Almanca öğretmeni (e10), "tablet bilgisayarımın öğrenci tabletleri veya etkileşimli tahta ile nasıl kullanılacağı ve en önemlisi bizim ders için nasıl kullanacağımız konusunda hiçbir bilgi verilmedi. Sadece tablet bilgisayarlar dağıtıld" şeklinde yaşamış olduğu sorun ve sorunun temel kaynağını ifade etmektedir. Fizik öğretmeni ise (e33), "tablet bilgisayarlar ve etkileşimli tahtalara yönelik materyal bulmak ve mevcut materyaller üzerinde işlem yapmak oldukça zor" şeklinde yaşamış olduğu sorunu ifade etmektedir. Çalışmada içeriğe yönelik belirlenen sorunların aynı zaman da etkileşimli tahtalarda da yaşandığı öğretmen ve öğrenciler tarafından sıklıkla vurgulanmaktadır. Böylelikle öğretmen ve öğrencilere etkileşimli tahtalara yönelik materyal bulunması ve hazırlanmasına yönelik eğitimlerin verilmesinin önemi bir kez daha ortaya çıkmaktadır. Bu doğrultuda araştırmacılar özellikle kısıtlamaların sınırlandırıması ve kullanııılara yönelik eğitimlerin verilmesi gerekliliğine vurgu yapmışlardır. Çalışmada tablet bilgisayarları derslerinde etkin olarak kullanan öğretmen ve öğrencilerin içerik sorununa ilişkin olarak;

- İnternet kısıtlamalarının kaldırılarak intiyaç duyulan içeriklere ulaşılmasına olanak sağlanması gerektiği $\left(f_{\mathrm{e}}=24, \%_{\mathrm{e}}=51.1 ; f_{\mathrm{k}}=183, \% \mathrm{k}=64.0\right)$,

- Derslere yönelik tablet bilgisayarlarda kullanılabilecek içeriklerin hazırlanması gerektiği $\left(f_{e}=23\right.$, $\%_{\mathrm{e}}=48.9 ; f_{\mathrm{k}}=101, \% \mathrm{k}=35.3$ ),

- İhtiyaç duyulan içeriklerin yüklenmesine izin verilmesi gerektiği $\left(f_{\mathrm{e}}=22, \%_{\mathrm{e}}=46.8 ; f_{\mathrm{k}}=103\right.$, $\% \mathrm{k}=36.0$ ) ve öğretmenlerin

- Tablet bilgisayar ve etkileşimli tahtalara yönelik içerik hazırlanması konusunda eğitim verilmesi gerektiği $\left(f_{\mathrm{e}}=15, \%_{\mathrm{e}}=31.9\right)$

doğrultusunda çözüm önerileri sunmaktadırlar. Çalışmaya katılan öğretmen ve öğrenciler bu öneriler dikkate alındığında derslere yönelik uygun materyallerin kolaylıkla bulunacağını ve hazırlanabileceğini belirtmektedirler. 


\section{Tablet bilgisayarlarda ergonomi ve sağlık açısından yaşanan sorunlar ve bu sorunlara ilişkin çözüm önerileri:}

Tablet bilgisayarlarda öğretmen ve öğrencilerin, ergonomi ve sağılk açısından karşılaştıkları sorunlar Tablo 7'de sunulmuştur.

Tablo 7. Tablet bilgisayarlarda Ergonomi ve Sağlık Açısından Yaşanan Sorunlar

\section{Öğretmen}

\begin{tabular}{|c|c|c|c|}
\hline & & $f_{\mathrm{e}}$ & $\%$ e \\
\hline$\overline{1 .}$ & Tablet bilgisayarlar göz sağlığımı olumsuz etkiliyor.* & 17 & 36,2 \\
\hline 2. & $\begin{array}{l}\text { Sınıf içine yayılan radyasyonun sağlığımı olumsuz etkileyebileceği } \\
\text { düşüncesi beni rahatsız ediyor. * }\end{array}$ & 15 & 31,9 \\
\hline
\end{tabular}

\section{Öğrenci}

\begin{tabular}{llcc}
\hline & & $\boldsymbol{k}_{\mathbf{k}}$ & $\mathbf{\%}$ \\
\hline 1. & Tablet bilgisayarlar göz sağlığımı olumsuz etkiliyor.* & 75 & 26,2 \\
\hline 2. & $\begin{array}{l}\text { Sınıf içine yayılan radyasyonun sağlı̆ımı olumsuz etkileyebileceği } \\
\text { düşüncesi beni rahatsız ediyor.* }\end{array}$ & 51 & 17,8 \\
\hline
\end{tabular}

Not : * İşaretli sorunlar öğretmen ve öğrenciler için ortak sorunlardır.

Öğrenme-öğretme sürecinde tablet bilgisayarlardaki ergonomi ve sağlık açısından yaşanan sorunlar incelendiğinde öğretmen ve öğrenciler için tüm sorunların ortak olduğu görülmektedir. Çalışma sonucunda öğretmen ve öğrencilerin tablet bilgisayarların göz sağlıklarına olumsuz etki ettiği veya edebileceği yönünde kaygılandıkları görülmektedir $\left(f_{\mathrm{e}}=17, \%_{\mathrm{e}}=36.2 ; f_{\mathrm{k}}=75, \%_{\mathrm{k}}=26.2\right)$. Ayrıca, tablet bilgisayarların sınıf içine radyasyon yaymasından $\left(f_{\mathrm{e}}=15, \%_{\mathrm{e}}=31.9 ; f_{\mathrm{k}}=51, \% \mathrm{k}=17.8\right)$ ve sağlıklarını olumsuz etkileyebileceği düşüncesinden dolayı tedirgin oldukları görülmektedir. Belirlenen bu sorunlara ilişkin olarak fizik öğretmeni (e11) ise "sınıf içinde 29 tane öğrenci tableti bir tanede bende üstüne birde etkileşimli tahta ve hepsi kablosuz ağ aracılıyla internete bağlı. Bu durumda da sınıf içi radyasyon miktarını düşünün. Dolayısıyla gelecekte sağlığımızın olumsuz etkilenmesi düşüncesi beni tedirgin ediyor" diyerek sağlık konusundaki endişesini dile getirmektedir. Konu ile ilgili 9. Sınıf öğrencisi (k98) ise "sürekli tabletimde oyun oynuyorum. Sanırım gözlerim bozulacak!" şeklinde tedirginliğini ifade etmektedir. Bu durum ile ilgili (k81) ise "tabletimden pdf olarak kitap okuyorum. Kitapları taşıma derdinden çoğunlukla kurtuldum, ama tabletten okumak gözlerimi çok yoruyor. Yazıları büyütmemde çok şeyi değiştirmiyor. Umarım gözlerim daha çok bozulmaz" şeklinde yaşamış olduğu sorunu ve tedirginliği belirtmektedir.

Öğrenme-öğretme ortamlarında yerlerini alan kablosuz iletişim araçları (tablet bilgisayarlar, akıllı telefonlar, vb.) elektromanyetik alan yaratan kaynaklardır ve bu kaynakların sağılk açısından ciddi sorunlar yaratabileceği yapılan çalışmalarda sıklıkla vurgulanmaktadır (bkz. Heinen, 2006; Baysal, 2011; Durusoy, Hassoy, Karababa, \& Özkurt, 2011; EMANET, 2011). Hatta bu soruna yönelik tablet bilgisayarların da içinde bulunduğu kablosuz iletişim teknolojilerinin (cep telefonları ve bilgisayarlar) insan sağlığı için risk oluşturabileceği ve okullarda kullanımının yasaklanması gerektiği doğrultusunda Avrupa Parlamentosu çevre komitesi bir rapor yayınlamıştır (Council of Europe, 2011). Ayrıca, Almanya, Avusturya, Fransa, İngiltere, Kanada ve Rusya gibi birçok ülkenin okullarında kablosuz iletişim teknolojilerinin kullanımı konusunda sınırlandırımasına yönelik çeşitli önlemler alınmaya başlanmıştır (bkz. Heinen, 2006; German Federal Government, 2007; CHS, 2007; Russian National Committee, 2008; PPS, 2011). Alanyazında tablet bilgisayarlara yönelik karşılaşılan diğer bir sorun ise göz sağlığına yönelik olumsuzlardır. Buna yönelik olarak Amerikan Optimetri Birliği (American Optometric Association- AOA) tabletler de dahil olmak üzere el ile kontrol edilebilir teknolojik cihazların görme sendromu, göz yorgunluğu, baş ağrısı, bulanık görme ve kuru göz gibi bazı sağlık sorunlarına neden olabildiği yönünde bir rapor yayınlamıştır (AFP Relaxnews, 2012). Ayrıca bilgisayar görme sendromu tanımı altında yapılan birçok çalışmada da bu sorunun ve bu soruna karşı alınabilecek önlemlerin önemi vurgulanmaktadır (bkz. Yan, Hu, Chen \& Lu 2008; Rosenfield, 2011). Bu noktada tablet bilgisayarlara yönelik ergonomi ve sağlık konusunda yaşanan sorunların ve tedirgin olunan unsurların giderilebilmesine yönelik olarak öğretmen ve öğrencilerin; 
- Tablet bilgisayarların yaydığı radyasyonu engelleyici tedbirlerin alınması gerektiği $\left(f_{e}=14\right.$, $\left.\%_{\mathrm{e}}=29.8 ; \mathrm{k}_{\mathrm{k}}=36, \% \mathrm{k}=12.6\right)$,

- Tablet bilgisayarların ergonomik kullanımına yönelik uzmanlarca bilgi verilmesi gerektiği $\left(f_{e}=9\right.$, $\% \mathrm{e}=19.1 ; f_{\mathrm{k}}=20, \% \mathrm{k}=7.0$ ),

- Olası sağlık sorunlarının önceden belirlenerek gerekli önlemelerin alınması gerektiği $(f=7$, $\left.\%_{\mathrm{e}}=14.9 ; f_{\mathrm{k}}=16, \% \mathrm{k}=5.6\right)$,

doğrultusunda çözüm önerileri sunmaktadırlar.

Çalışmayı genel olarak değerlendirdiğimizde öğretmen ve öğrencilerin tablet bilgisayarlarla ilgili öğrenme ve öğretme sürecinde sıklıkla sorun yaşadıkları görülmektedir. Bu doğrultuda özellikle kullanıma yönelik sorunların öğretmenler tarafından daha çok hissedildiği belirlenmiştir. Yaşanan teknik sorunlarda ise öğretmen ve öğrenciler arasında hiçbir farklıı̆ın olmadığı görülmektedir. Ayrıca öğretmenler başta olmak üzere öğrencilerinde tablet bilgisayarlara yönelik ergonomi ve sağlık konusunda tedirginlik hissettikleri ve olası sorunları öngörebildikleri belirlenmiştir. Çalışmada başta tablet bilgisayar kullanımına yönelik öğretmenlerin öğrencilerden daha fazla sorun yaşamalarının temel nedeni olarak kuşak farklııkları gösterilebilir. Bu doğrultuda öğrenciler Z (1995 ve sonrası doğumlu) kuşağı özelliği gösterirken öğretmenler ise ağırlıklı olarak X (1977-1994) ve Y (1966-1976) kuşağı özellikleri göstermektedirler (bkz. Schroer, 2008). Dijital nesil olarak da adlandırılan Z kuşağının diğer kuşaklardan farklı olarak öne çıkan özelliklerinden biride, hep yanlarında taşıdıkları mobil cihazları iletişim ve bilgiye ulaşma aracı olarak kullanmalarıdır (Schroer, 2008; Ivanova \& Smrikarov, 2009). Dolayısıyla kuşaklar arasındaki bu farklılık yeni teknolojinin kabul edilip kullanılmasına yansımaktadır. $\mathrm{Bu}$ doğrultuda tüm bu sorunlar ve kullanıcılar arasındaki farklııklar dikkate alınarak sorunların giderilmesine yönelik gerekli önlemler alınmalıdır.

\section{Sonuç ve Öneriler}

\section{Sonuçlar}

Bu araştırmada, ortaöğretim kurumlarında görev yapan öğretmen ve bu kurumlarda öğrenim gören öğrencilerin tablet bilgisayar kullanımı sırasında karşılaştıkları sorunların ve bu sorunlara ilişkin çözüm önerilerinin belirlenmesi amaçlanmıştır. Bu doğrultuda çalışma ortaöğretim kurumlarında görev yapan tablet bilgisayarlarını aktif olarak derslerinde kullanan öğrenciler ve farklı alan öğretmenleri üzerinde yürütülmüştür. Çalışma katılımcılarının aktif olarak tablet bilgisayar kullanan öğretmen ve öğrencilerden oluşuyor olması, tablet bilgisayarlara yönelik karşılaşılması muhtemel sorunların değil, aktif olarak kullanımı sırasında karşılaşılan sorunların belirlenmesi açısından oldukça önemlidir. Ayrıca, çalışma grubunun ortaöğretim kurumlarında farklı branşlarda görev yapan öğretmenler seçilmiş olması da çalışma sonuçlarının genellenebilirliği açısından önemli bir unsurdur. Bu kapsamda öğretmen ve öğrencilerin tablet bilgisayar kullanımı sırasında yaşamış oldukları sorunlara yönelik dikkat çekici bulgulara ulaşılmış ve bu sorunların çözümüne ilişkin öneriler geliştirilmiştir. Bu doğrultuda gerçekleştirilen çalışmada yapılan analizler sonucunda öğretmen ve öğrencilerin tablet bilgisayarlara ilişkin sorunları; öğrenme-öğretme sürecinde yaşanan sorunlar, donanıma yönelik sorunlar, yazılıma yönelik sorunlar, içeriğe yönelik sorunlar, ergonomi ve sağılık açısından sorunlar olmak üzere beş alt boyutta ele aldıkları ve bu doğrultuda çözüm önerileri sundukları belirlenmiştir.

Öğrenme-öğretme sürecinde tablet bilgisayarların kullanımına yönelik yaşanan sorunların önem sıraları öğretmen ve öğrenciler açısından farklılık gösterse de çoğu sorununun ortak olduğu görülmektedir. Yapılan çalışma sonucunda öğrenme-öğretme sürecinde tablet bilgisayarların amacı dışında kullanılmasının öğretmen ve öğrenciler için en önemli sorun olarak görülmektedir. Özellikle öğrenciler tarafından oyun oynamak, müzik dinlemek ve film izlemek amacıyla sıklıkla kullanıldığı öğretmenler tarafından belirtilmektedir. Öğrenme-öğretme sürecinde tablet bilgisayarlara yönelik yaşanan diğer ortak sorunlar ise: sınıftaki çalışma ortamını olumsuz etkilemesi; sınıf içindeki etkileşimi ve katııımı da olumsuz etkilemesi; derse ilişkin faaliyetlerde zaman kaybına neden olması; işlem yapılması için uygun olmaması ve tablet bilgisayarların basılı materyallere olan ilgiyi azaltması yönündeki kaygılarıdır. Genel olarak tablet bilgisayarların öğrenme-öğretme sürecinde kullanımında yaşanan sorunlar incelendiğinde, belirlenen sorunları öğretmenlerin ve öğrencilerden daha fazla vurguladıkları görülmektedir. Yapılan çalışmada öğretmenler öğrencilerden farklı olarak öğrencilerin ders sırasında tablet bilgisayarlara 
odaklanıp, dersten uzaklaşıımasını önemli bir sorun olarak görmektedirler. Özellikle bu sorunun öğrencilerin tablet bilgisayarlarında ne yaptıklarını göremiyor olmalarından kaynaklandığı öğretmenler tarafından ifade edilmektedir. Öğrencilerin kullanmış olduğu tablet bilgisayarların özellikle ders sırasında öğretmen tarafından kontrol edilememesinden kaynaklı olduğu belirtilen bu sorunların sınıf yönetimi, etkileşim ve katılımı da olumsuz etkilediği de öğretmenler tarafından sıklıkla vurgulanmaktadır. Çalışmaya katılan öğrenciler ise öğretmenlerden farklı olarak tablet bilgisayarın derste dikkat dağılmasına neden olduğuna yöneliktir. Çalışmaya katılan öğretmen ve öğrenciler yaşamış oldukları sorunlara yönelik çözüm önerileri sunmuşlardır. Katılımcıların bu boyuttaki çözüm önerileri ise tablet bilgisayarların: amacı dışında kullanılmasının engellenmesi gerektiği; etkileşimli tahta ve diğer tablet bilgisayarların arasındaki etkileşimin sağlanması gerektiği; öğrenme öğretme ortamında etkin kullanılabilmesi için eğitimlerin verilmesi gerektiği; etkin kullanımına yönelik yardımcı alan uzmanı kişilerin görevlendirilmesi gerektiği ve öğretmenler öğrencilerden farklı olarak öğrenci tabletlerinin öğretmenler tarafından kontrol edilebilmesinin sağlanması gerektiği şeklinde sıralanmaktadır.

Öğrenme-öğretme sürecinde tablet bilgisayarlarda donanıma ilişkin sorunlar incelendiğinde öğretmen ve öğrenciler için önem sıraları farklı olsa da tüm sorunların ortak olduğu görülmektedir. Çalışma sonucunda tablet bilgisayarların yavaş çalışması ve tutukluk yapması, öğretmen ve öğrenciler için en önemli donanımsal sorun olarak görüldüğü belirlenmiştir. Yapılan çalışma sonucunda tablet bilgisayar ve diğer cihazlarla bağlantı sorunlarının yaşanması; çevre birimlerinin çalışmaması; şarjının çabuk bitmesi ve kısa sürede şarj edilememesi ve teknik sorunların kısa sürede çözülememesi ise öğretmen ve öğrencilerin donanıma yönelik diğer ortak sorunlarıdır. Bu doğrultuda yapılan çalışma sonucunda tablet bilgisayarlara yönelik yaşanan donanımsal sorunların daha çok teknik sorunlar olduğu ve genellikle bu sorunlara teknik uzmanlarca müdahale edilerek çözülebileceği görülmektedir. Ayrıca, kullanıma yönelik bilgi ve beceri eksikliğinin de bu sorunların oluşmasında etkili olduğu belirlenmiştir. Bu süreçte öğretmen ve öğrencilerin tablet bilgisayarlarda karşılaşılan donanımsal sorunlarla baş edebilme yeterliliklerinin kazandırıması gerektiği görülmektedir. Bu doğrultu tablet bilgisayarları derslerinde etkin olarak kullanan öğretmen ve öğrenciler öğrenme-öğretme sürecinde tablet bilgisayarlarda donanıma yönelik yaşanan sorunlara ilişkin: donanımsal sorunların kısa zamanda çözümünün sağlanması gerektiği; yaşanan teknik sorunların çözümünde öğretmen ve öğrencilere teknik destek sağlanması gerektiği; teknik bilgileri de kapsayacak nitelikte eğitimlerin verilmesi gerektiği; donanımsal olarak zamanla yenilenmesi gerektiği doğrultusunda çözüm önerileri sunmaktadırlar.

Öğrenme-öğretme sürecinde tablet bilgisayarlarda yazılıma ilişkin sorunlar incelendiğinde öğretmen ve öğrenciler için tüm sorunların ortak olduğu görülmektedir. Çalışma sonucunda tablet bilgisayarlarda kısıtlamaların (program, yazııı, eklenti vb.) etkili kullanımını engellemesi öğretmen ve öğrenciler için en önemli yazılımsal sorun olarak görüldüğü belirlenmiştir. Aynı zamanda bu kısıtlamaların tablet bilgisayarlarda bulunan kendi yazılımı dışında farklı yaziımlara intiyaç duyulması sorunlarının giderilmesine de engel olduğu görülmektedir. Ayrıca, donanımsal yetersizliğe de bağlı olarak, tablet bilgisayarların yüksek sistem gerektiren programlar için yetersiz kalması da bir sorun olarak karşımıza çıkmaktadır. Çalışmada belirlenen bir diğer sorunda öğretmen ve öğrencilerin kişisel bilgilerinin gizliliği ve güvenliği ile ilgili tedirginlik olmalarıdır. Bu soruna ilişkin kullanııılara özel olarak tanımlanan tabletlerde yaptıkları işlemlerin takip edilebilir olması ve tablet bilgisayarların ortak bir ağ üzerinden bağlanması ve bu doğrultu da kişisel bilgilerin güvenliğinin sağlanamayabileceği yönündeki endişelerinin çalışmada sıklıkla vurgulanmıştır. Bu doğrultuda tablet bilgisayarları derslerinde etkin olarak kullanan öğretmen ve öğrenciler öğrenme-öğretme sürecinde tablet bilgisayarlarda yazilıma yönelik yaşanan sorunlara ilişkin: yazııımsal kısıtlamaların kaldırıması gerektiği; ihtiyaç duyulan yazııımların yüklenmesine izin verilmesi gerektiği; yaşanan yazılımsal sorunların kısa zamanda çözüm sağlanması gerektiği; yazılımsal olarak zamanla güncellenmesi gerektiği; yaşanan yazıımsal sorunların çözümünde öğretmen ve öğrencilere destek sağlanması gerektiği doğrultusunda çözüm önerileri sunmaktadırlar.

Öğrenme-öğretme sürecinde tablet bilgisayarlardaki derse yönelik içeriklere ilişkin sorunlar incelendiğinde tüm sorunların ortak olduğu görülmektedir. Çalışma sonucunda tablet bilgisayarlardaki yazılımsal kısıtlamaların yanı sıra tablet bilgisayarlar üzerinden bazı yararlı site ve içeriklere erişilememesi de öğretmen ve öğrenciler açısından önemli sorun olduğu görülmektedir. Özellikle 
öğrencilerinde önemli bir sorun olarak gördükleri bu kısıtlamaların sınırlandırıması gerektiği sıklıkla vurgulanmaktadır. Bu sınırlandırmalarla da paralel olarak istenilen içeriğe ulaşımaması ve tablet bilgisayarlarda kullanılabilecek nitelikte derse yönelik içerik bulmakta zorluk yaşanması sorunu yaşanmaktadır. Ayrıca tablet bilgisayarlar üzerinde materyal hazırlamakta ve düzenlemekte zorluk yaşanması da bir diğer sorun olarak karşımıza çıkmaktadır. Bu doğrultu tablet bilgisayarları derslerinde etkin olarak kullanan öğretmen ve öğrenciler öğrenme-öğretme sürecinde tablet bilgisayarlarda derse yönelik içeriklere ilişkin yaşanan sorunlara: derslere yönelik içeriklerin hazırlanması gerektiği; internet kısıtlamalarının kaldırılarak intiyaç duyulan içeriklere ulaşılmasına olanak sağlanması gerektiği; ihtiyaç duyulan içeriklerin yüklenmesine izin verilmesi gerektiği doğrultusunda çözüm önerileri sunmaktadırlar. Ayrıca, çalışmaya katılan öğretmenlerin büyük çoğunluğu derslerde kullanılabilecek nitelikte içeriklerin hazırlanmasına yönelik geniş kapsamlı hizmetiçi eğitim kurslarının verilmesi gerektiği doğrultusunda çözüm önerisi sunmuşlardır.

Öğrenme-öğretme sürecinde tablet bilgisayarlardaki ergonomi ve sağlık açısından yaşanan sorunlar incelendiğinde öğretmen ve öğrenciler için tüm sorunların ortak olduğu görülmektedir. Çalışma sonucunda tablet bilgisayarların öğretmen ve öğrencilerin göz sağı̆ğını ve sınıf içine yayılan radyasyonun olumsuz etkileyebileceği düşüncesinden dolayı tedirgin oldukları görülmektedir. Bu doğrultuda tablet bilgisayarlara yönelik ergonomi ve sağlık konusunda yaşanan sorunların ve tedirgin olunan unsurların giderilebilmesine yönelik olarak öğretmen ve öğrenciler; tablet bilgisayarların yaydığı radyasyonu engelleyici tedbirlerin alınması gerektiği; tablet bilgisayarların ergonomik kullanımına yönelik uzmanlarca bilgi verilmesi gerektiği ve olası sağılı sorunlarının önceden belirlenerek gerekli önlemelerin alınması gerektiği doğrultusunda çözüm önerileri sunmaktadırlar.

Gelişmiş birçok ülkede olduğu gibi 2011 yılından itibaren ülkemiz ortaöğretim kurumlarında da yerini almaya başlayan tablet bilgisayarların genel olarak öğrenme-öğretme sürecine olumlu katkı sağlaması beklenmektedir. Bu doğrultuda alanyazında yapılan çalışmaların çoğunda da öğretmen ve öğrencilerin tablet bilgisayarların doğru kullanım stratejileri ile öğrenme-öğretme ortamına getirebileceği muhtemel katkıları ön plana çıkmaktadır. Ancak, toplumsal ihtiyaçlar doğrultusunda yönünü belirleyen teknolojinin amaca uygunluğunu ve sürdürebilirliğini yine onu kullananlar belirlemektedir. Bu durumda yeni teknolojinin uygulanabilirliği, toplumun yapısına ve zamana bağı olarak değişim göstermektedir. Araştırma sonucunda öğretmen ve öğrencileri tablet bilgisayarlara yönelik birçok olumlu yönü ifade ettikleri görülmektedir. Ancak, yapılan çalışmanın amacı gereği öğretmen ve öğrencilerin tablet bilgisayar kullanımı sırasında yaşamış oldukları sorunlara ve bu sorunlara karşı çözüm önerilerine odaklanıımışıı. Bu doğrultuda belirlenen sorunların giderilmesi ve bu sorunlara karşı geliştirilen önerilerin dikkate alınarak gerekli tedbirleri alınması tablet bilgisayarların öğrenme-öğretme ortamına katkısını arttıracağı öğretmen ve öğrenciler tarafından belirtilmiştir.

\section{Öneriler}

Öğrenme-öğretme ortamına sunulan yeni teknolojilerin sürece etkilerinin ve varsa aksaklıkların belirlenmesi, teknolojinin daha etkin kullanılabilmesi için doğru stratejilerin geliştirilmesine katkı sağlar. Bu doğrultuda öğrenme ortamında yeni teknoloji kullanan öğretmen ve öğrencilerin sürece ilişkin sorunlarının belirlenmesi ve bu sorunlara yönelik beklentilerini karşılayacak adımlar atıması gerekmektedir. Bu amaçla gerçekleştirilen araştırma sonuçlarına dayalı olarak getirilebilecek öneriler ise şunlardır;

- Belirlenen sorunların giderilmesi ve bu sorunlara karşı geliştirilen önerilerin dikkate alınarak gerekli tedbirleri alınması tablet bilgisayarların öğrenme-öğretme ortamına katkısını arttıracaktır.

- Tablet bilgisayarların amacı dışında kullanılması engellenmelidir.

- Tablet bilgisayarlarda yaşanan donanımsal ve yazııımsal sorunların kısa zamanda çözülmesi sağlanmalıdır.

- Tablet bilgisayarların donanımsal ve yazılımsal olarak zamanla yenilenmesi sağlanmalıdır.

- Öğretmen ve öğrencilerin teknik sıkıntılarında yardımcı olacak, güncel yazıım ve ders araçlarına ulaşabilecekleri bir birim oluşturulmalıdır.

- Tablet bilgisayarların öğrenme-öğretme ortamında etkin kullanılabilmesi için öğretmen ve öğrencilere yönelik kapsamlı eğitimler verilmelidir. 
- Tablet bilgisayarlarda yazıım ve internete yönelik kısıtlamalar kaldırımalı ya da daha esnek bir güvenlik sistemi sağlanmalıdır.

- Tablet bilgisayarlara yönelik uygun ders materyalleri geliştirilmelidir.

- Tablet bilgisayarların etkili kullanımına yönelik bir kılavuz hazırlanmalı ve bu kılavuzun içeriği sürekli güncellenmelidir.

- Tablet bilgisayarlardan kaynaklanabilecek sağlık sorunları öngörülmeli ve bu konuda gerekli tedbirler alınmalıdır.

- Tablet bilgisayarların etkin kullanımına yönelik yardımcı alan uzmanı kişiler görevlendirilmelidir.

- Bilişim teknolojilerine yönelik derslerin tüm kademelerde zorunlu olması sağlanarak ve bu doğrultuda öğrencilere teknoloji kullanımı yönündeki eğitimler arttırımalıdır.

- Öğretmen yetiştiren kurumlar tüm alan öğretmenlerine Milli Eğitim Bakanlığının beklentilerini karşılayabilecek nitelikte eğitimde teknoloji kullanımına dersler konulmalı ve buna yönelik yeniden düzenlenme yapılmalıdır.

- Bu çalışma ilköğretim kademesinde de (ilkokul ve ortaokul) gerçekleştirilmelidir.

\section{Kaynakça}

AFP Relaxnews. (2012). iPads and tablets may cause eye problems or 'computer vision syndrome'. Daily News. http://www.nydailynews.com/life-style/health/ipads-tablets-eye-problemscomputer-vision-syndrome-article-1.1038685 adresinden 22.06.2013 tarihinde alınmıştır.

Amelink, C., Scales, G., \& Tront, J. (2012). Student use of the Tablet PC: Impact on student learning behaviors. Advances In Engineering Education, 3(1), 1-17.

Baysal, U. (2011). Elektromanyetik alanların sağlık etkilerinin değerlendirilmesi. Elektromanyetik Alanlar ve Etkileri Sempozyumu (258-261), Ezgi Matbaacllık, İstanbul.

BBC (2011). Digital textbooks open a new chapter. http://www.bbc.co.uk/news/business-15175962 adresinden 20.06.2013 tarihinde alınmıştır.

Bozdoğan, A., \& Uzoğlu, M. (2012). The development of a scale of attitudes toward tablet pc. Mevlana International Journal Of Education, 2(2), 85-95.

CHS (2007). WiFi in public libraries in Paris: Moratorium. The hygiene and security committee of Paris city's cultural management voted this measure. http://www.nextup.org/pdf/France2WiFiInPublicLibrariesInParisMoratorium30112007.pdf $\quad$ adresinden 18.05.2013 tarihinde alınmıştır.

Corbin, J. M., \& Strauss, A. C. (2007). Basics of qualitative research: Techniques and procedures for developing grounded theory. Thousand Oaks, CA: Sage Publication.

Council of Europe (2011). The potential dangers of electromagnetic fields and their effect on the environment. http://assembly.coe.int/ASP/Doc/XrefViewPDF.asp?FileID=13137\&Language=en adresinden 20.06.2013 tarihinde alınmıştır.

Dağtaş, A. (2013). Öğretmenlerin Basılı Sayfa ve Ekrandan Okuma Tercihleri İle Eğitimde Elektronik Metin Kullanımına Yönelik Görüşleri. Electronic Turkish Studies, 8(3), 137-161.

Dallas, M. E. (2012). Health Day. Overloaded Backpacks Can Injure Kids: Experts. http://consumer.healthday.com/Article.asp?AID=667521 adresinden 21.06.2013 tarihinde alınmıştır.

Dundar, H., \& Akcayir, M. (2012). Tablet vs. Paper: The Effect on Learners' Reading Performance. International Electronic Journal Of Elementary Education, 4(3), 441-450. 
Durusoy, R., Hassoy, H., Karababa, A. O., \& Özkurt, A. (2011). Bornova'da 2150 lise öğrencisinin cep telefonu kullanımı ve ilişkili semptomlar. Elektromanyetik Alanlar ve Etkileri Sempozyumu (203-207). Ezgi Matbaaclık, İstanbul.

El-Gayar, O., Moran, M., \& Hawkes, M. (2011). Students' Acceptance of Tablet PCs and Implications for Educational Institutions. Educational Technology \& Society, 14(2), 58-70.

Ellington, A. J., Wilson, J. H., \& Nugent, J. S. (2011). Use of Tablet PCs to Enhance Instruction and Promote Group Collaboration in a Course to Prepare Future Mathematics Specialists. Mathematics And Computer Education, 45(2), 92-105.

EMANET (2011). Elektromanyetik alanlar ve etkileri sempozyumu sonuç bildirgesi. Elektromanyetik Alanlar ve Etkileri Sempozyumu (275-277), Ezgi Matbaacilık, İstanbul.

Enriquez, A. G. (2010). Enhancing student performance using tablet computers. College Teaching, 58(3), 77-84.

Ferrer, F. F., Belvi's, E. E., \& Pa 'mies, J. J. (2011). Tablet PCs, academic results and educational inequalities. Computers \& Education, 56(1), 280-288.

Fister, K., \& McCarthy, M. L. (2008). Mathematics Instruction and the Tablet PC. International Journa Of Mathematical Education In Science And Technology, 39(3), 285-292.

Galligan, L., Loch, B., McDonald, C., \& Taylor, J. A. (2010). The Use of Tablet and Related Technologies in Mathematics Teaching. Australian Senior Mathematics Journal, 24(1), 38-51.

German Federal Government, (2007). Radiation exposure due to wireless Internet-Networks (WLAN). http://www.icems.eu/docs/deutscher_bundestag.pdf adresinden 23.06.2013 tarihinde alınmıştır.

Gorgievski, N., Stroud, R., Truxaw, M., \& DeFranco, T. (2005). Tablet PC: A Preliminary Report on a Tool for Teaching Calculus. International Journal For Technology In Mathematics Education, 12(3), 95-102.

Gök, T. (2012). Real-Time Assessment of Problem-Solving of Physics Students Using Computer-Based Technology. Hacettepe University Journal Of Education, 43, 210-221.

Grzybowski, M. (2013). Educational Technologies in South Korea. General and Professional Education. $1 / 2013,3-9$.

Hawkes, M., \& Hategekimana, C. (2009). Impacts of Mobile Computing on Student Learning in the University: A Comparison of Course Assessment Data. Journal of Educational Technology Systems, 38(1), 63-74.

Heinen, K. (2007). WLAN is to be banished from the school sphere. http://omega.twoday.net/stories/3974159/ adresinden 22.05.2013 tarihinde alınmıştır.

Hieb, J. L., \& Ralston, P. S. (2010). Tablet PCs in Engineering Mathematics Courses at the J.B. Speed School of Engineering. International Journal Of Mathematical Education In Science Ana Technology, 41(4), 487-500.

Horton, L. M., Kim, K., Kothaneth, S., \& Amelink, C. T. (2011). Macroergonomics analysis of instructional technology diffusion: A case study on Tablet PC adoption. Virginia, ABD: Virginia Tech College of Engineering.

Ivanova, A., \& Smrikarov, A. (2009). The new generations of students and the future of e-learning in higher education. International Conference on e-Learning and the Knowledge Society - $e$ Learning'09. Europeun Commission, Berlin, Germany. 
Jones, J. L., \& Sinclair, B. (2011). Assessment on the go: Surveying students with an iPad. Journal ot Library Innovation, 2(2), 22-35.

Karasar, N. (2008). Bilimsel Araştırma Yöntemi (18.Baskı). Nobel Yayın Dağııı, Ankara.

Keser, H., \& Çetinkaya, L. (2013). Öğretmen ve Öğrencilerin Etkileşimli Tahta Kullanımına Yönelik Sorunları ve Çözüm Önerileri. Electronic Turkish Studies, 8(6), 377- 403.

Koile, K., \& Singer, D. (2006). Development of a Tablet-PC-based System to Increase InstructorStudent Classroom Interactions and Student Learning. In D. Berque, J. Prey, and R. Reed (editors), The Impact of Pen-based Technology on Education: Vignettes, Evaluations, ano Future Directions, Purdue University Press. p115-122.

Kowalski, S. E., Kowalski, F. V., \& Gardner, T. Q. (2009). Lessons learned when gathering real-time formative assessment in the university classroom using Tablet PCs. 39th ASEE/IEEE Frontiers in Education Conference, San Antonio, TX.

Lanir, L. (2012). Decoded Science. Digital Information Overload Overwhelms and Distracts Students. http://www.decodedscience.com/digital-information-overload-overwhelms-and-distractsstudents/19798 adresinden 18.06.2013 tarihinde alınmıştır.

Le Ber, J., Lombardo, N., \& Quilter, J. (2008). Tablet PC use enhances teaching and student learning. Journal of Electronic Resources In Medical Libraries, 5(1), 17-31.

Loch, B., Galligan, L., Hobohm, C., \& McDonald, C. (2011). Learner-centred mathematics and statistics education using netbook tablet PCs. International Journal of Mathematical Education in Science \& Technology, 42(7), 939-949.

Maxwell, J. A. (1996). Qualitative research design: An interpretative approach. Thousand Oaks, CA: Sage

MEB (2011). Eğitimde FATİH Çalıştayı. http://fatihprojesi.meb.gov.tr/site/haberincele.php?id=12 adresinden 09.01.2013 tarihinde alınmıştır.

Mendelsohn, T. (2012). The Independent. Ten great free education apps for the iPad. http://www.independent.co.uk/student/student-life/technology-gaming/ten-great-freeeducation-apps-for-the-ipad-6297153.htm adresinden 19.05.2013 tarihinde alınmıştır.

Mills, M. (2012). PBS. National PBS Survey Finds Teachers Want More Access to Classroom Tech. http://www.pbs.org/about/news/archive/2012/teacher-survey-fetc/ adresinden 19.05.2013 tarihinde alınmıştır.

Moran, M. M., Hawkes, M. M., \& El Gayar, O. O. (2010). Tablet personal computer integration in higher education: applying the unified theory of acceptance and use technology model to understand supporting factors. Journal of Educational Computing Research, 42(1), 79-101.

Mulholland, J. B. (2011). IPads strengthen education. Government Technology, 24(4), 20-24.

$\mathrm{Ni}$, K. (2013). The Epoch Times. Managing the Transition to Digital Textbooks. http://www.theepochtimes.com/n2/united-states/managing-the-transition-to-digitaltextbooks-344930.html adresinden 19.06.2013 tarihinde alınmıştır.

Nie, M., Armellini, A., Witthaus, G., \& Barklamb, K. (2011) How do e-book readers enhance learning opportunities for distance work-based learners?. Research in Learning Technology, 19(1), 1938. 
Phillips, P., \& Loch, B. (2011). Building Lectures and Building Bridges with Socio-Economically Disadvantaged Students. Educational Technology \& Society, 14(3), 240-251.

PPS (2011). Parent suing portland, oregon public school system indistrict court citing breach of 14th amendment right to choice by installing wifi. http://media.withtank.com/b5e48bb89c.pdf adresinden 23.05.2013 tarihinde alınmıştır.

Price, E., \& Simon, B. (2009). Ubiquitous Presenter: A Tablet PC-Based System to Support Instructors and Students. Physics Teacher, 47(9), 570-573.

Rawat, K. S., Riddick, G. B., \& Moore, L. J. (2008). Work in progress-integrating mobile tablet-PC technology and classroom management software in undergraduate electronic engineering technology courses. 38th Annual Frontiers in Education Conference, Saratoga Springs, NY.

Rogers, J. W., \& Cox, J. R. (2008). Integrating a Single Tablet PC in Chemistry, Engineering, and Physics Courses. Journal of College Science Teaching, 37(3), 34-39.

Romney, C. A. (2010). Tablet PCs in undergraduate mathematics. 40th ASEE/IEEE Frontiers in Education, Washington, DC.

Romney, C. A. (2011). Tablet PC use in freshman mathematics classes promotes STEM retention. 41 th ASEE/IEEE Frontiers in Education Conference, Rapid City, SD.

Roschelle, J., Tatar, D., Chaudhury, S., Dimitriadis, Y., Patton, C., \& DiGiano, C. (2007). Ink, Improvisation, and Interactive Engagement: Learning with Tablets. Computer, 40(9), 42-48.

Rosenfield M. (2011). Computer vision syndrome: a review of ocular causes and potential treatments. Ophthalmic \& Physiological Optics, 31(5), 502-515.

Russian National Committee, (2008). Children and mobile phones: the health of the following generations is in danger. http://www.radiationresearch.org/pdfs/rncnirp children.pdf adresinden 24.05.2013 tarihinde alınmıştır.

Schroer, W. J. (2008). Generations X, Y, Z and the Others. The Journal of the Household Goods Forwarders Association of America Inc., XL, 9-11.

Shurtz, S., Halling, T. D., \& McKay, B. (2011). Assessing user preferences to circulate iPads in an Academic Medical Library. Journal of Electronic Resources in Medical Libraries, 8(4), 311-324.

Siozos, P., Palaigeorgiou, G., Triantafyllakos, G., \& Despotakis, T. (2009). Computer based testing using "digital ink": Participatory design of a Tablet PC based assessment application for secondary education. Computers \& Education, 52(4), 811-819.

Sneller, J. (2007). The tablet PC classroom: Erasing borders, stimulating activity, enhancing communication. 37th Annual ASEE/IEEE Frontiers in Education Conference Prooceeding Book, (S3J-6- S3J-10).

Stickel, M. M. (2009). Impact of lecturing with the tablet PC on students of different learning styles. 39th ASEE/IEEE Frontiers in Education Conference, San Antonio, TX.

Tavşancıl. E., \& Aslan. E. A. (2001). İçerik analizi ve Uygulama Örnekleri. Ankara: Epsilon Yayınları.

Tofan, D. C. (2010). Using a Tablet PC and OneNote 2007 to Teach Chemistry. Journal of Chemica Education, 87(1), 47-48.

Toppo, G. (2012). USA TODAY. Obama wants schools to speed digital transition. http://usatoday30.usatoday.com/news/education/story/2012-01-31/schools-etextbooks/52907492/1 adresinden 18.05.2013 tarihinde alınmıştır. 
Tront, J. G., \& Prey, J. C. (2007). Workshop - tablet PCs in engineering education \& research.

Uzoglu, M., \& Bozdogan, A. (2012). An examination of Preservice Science Teachers' views related to use of tablet PCs in science and technology course in terms of different variables. Mevlana International Journal of Education, 2(1), 1-14.

Smart Education in Korea (2011). Smart Education in Korea: South Korea's Making the Switch to Digital Textbooks. http://www.advancedtechnologykorea.com/8000 adresinden 18.05.2013 tarihinde alınmıştır.

Wimmer, R. D. ve Dominick, J. R. (2003). Mass Media Research: An Indroduction (7th ed.). Belmont, CA: Wadsworth.

Wolcott, H. F. (1990). On seeking-and rejecting-validity in qualitative research. (Ed.) E. W. Eisner. \& A. Peshkin Qualititative Inquiry in Education the Coutinuing Debate (121-152). New York: Teachers Collage Press.

Yan, Z., Hu, L, Chen, H., \& Lu, F. (2008). Computer Vision Syndrome (CVS): A widely spreading but largely unknown epidemic among computer users. Computers in Human Behavior, 24(5), 2026-2042.

Yıldırım, A., \& Şimşek, H. (2008). Sosyal Bilimlerde Nitel Araştırma Yöntemleri (6.Baskı). Ankara: Seçkin Yayıncilık.

Yoon, C., \& Sneddon, J. (2011). Student perceptions of effective use of tablet PC recorded lectures in undergraduate mathematics courses. International Journal of Mathematical Education In Science And Technology, 42(4), 425-445.

\section{EXTENDED ABSTRACT}

As in many developed countries, tablet PCs have begun to be used since 2011 in high education institutions of Turkey, are generally supposed to contribute positively to the process of teachinglearning. However, technology, fixing its direction in line with social needs, its fitness for purpose and sustainability are determined by those who make use of it. In this case, applicability of new technology changes in accordance with the social structure and date. Determiningtheproblemsduringtheimplementationandtakingnecessarymeasuresaccordinglyare of vital importance for the improvement of this change in a positive way. In this study which was carried out in this direction, it is aimed to determine the problems that are encountered by the teachers and students of high education institutions while using tablet PCs and to develop solution suggestions for these problems.

In this study which is conducted as a survey model, the data is categorized by content analysis method. Study group for this research is composed of high education teachers from different branches $(f=47)$ actively using tablet PCs in the lectures and their students ( $f=286)$ in the academic term 20122013. Data obtained by open-ended questionnaire during the research has been analyzed and interpreted by inductive encoding technique, frequency analysis and descriptive content analysis. As result of the analysis carried out in this research which was performed in this direction, it has been seen that teachers and students evaluate the problems related with tablet PCs under the following five sub-dimensions and present solution suggestions accordingly: problems encountered during learningteaching process, problems related with hardware, problems related with software, problems related with the context, problems in view of ergonomics and health.

The most common problems that are faced, concerning the usage of the tablet PCs, are the software, context and internet restrictions which limit efficiency, unavailability of suitable materials for lectures, and lack of precautions against insufficient knowledge and skills. In this direction, it is observed that 
teachers are more aware of the usage problems. However, there is no difference between teachers and students in terms of awareness of the technical problems. In addition to teachers, students also feel discomfortable concerning ergonomics and health of tablet PCs, and foresee the possible problems. Leading solution alternatives suggested by the participants, as regards the problems are; needs for lifting restrictions on software and internet, needs for developing appropriate lecture materials, needs for comprehensive training of teachers and students, needs for a fast solution for the existing hardware and software problems, and need for taking precautions for the possible health problems. It is suggested by teachers and students that tablet PCs will be able to contribute positively to the process of teaching-learning when the problems that are found by the research are solved and the suggestion solutions that are provided are taken into consideration through necessary precautions. 